\title{
CALCULATION OF SOIL HYDRAULIC CONDUCTIVITY FROM SOIL-WATER RETENTION RELATIONSHIPS
}

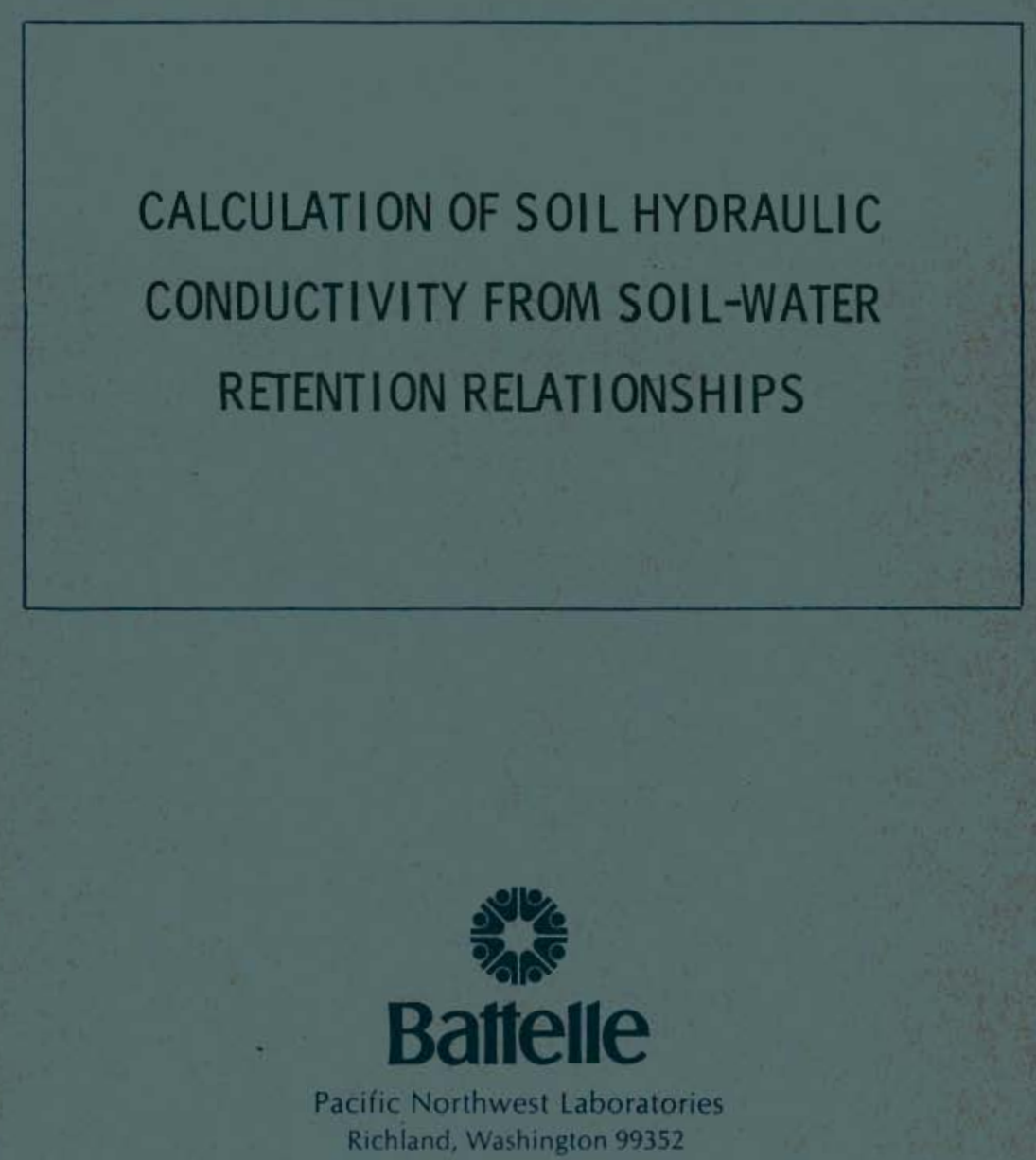

Richland, Washington 99352

1973

Prepared for the U.S. Atomic Energy Commission under Contract AT(45-1):1830 
NOTICE

The report was prepared as an account of work sponsored by the United States Government. Neither the United States nor the United States Atomic Energy Commission, nor any of their employees, nor any of their contractors, subcontractors, or their employees, makes any warranty, express or implied, or assumes any legal liability or responsibility for the accuracy, completeness or usefulness of any information, apparatus, product or process disclosed, or represents that its use would not infringe privately owned rights.

\section{PACIFIC NORTHWEST LABORATORY operated by \\ BATTELLE \\ for the \\ U.S. ATOMIC ENERGY COMMISSION \\ Under Contract AT(45-1)-1830}
Printed in the United States of America Available from
National Technical Information Service
U.S. Department of Commerce
5285 Port Royal Road
Springfield, Virginia 22151
Price: Printed Copy \$4.00; Microfiche \$1.45

i

AEC.RL NICHLAND, wASH. 


\title{
33679000622615
}

\section{CALCULATION OF SOIL HYDRAULIC CONDUCTIVITY FROM SOIL-WATER RETENTION RELATIONSHIPS}

by

\author{
A. E. Reisenauer
}

\begin{abstract}
Water and Land Resources Department
\end{abstract}
This report is based on work sponsored by the Atlantic Richfield Hanford Company under United States Atomic Energy Commission Contract AT (45-1)-2130

BATTELLE PACIFIC NORTHWEST LABORATORIES RICHLAND，WASHINGTON 99352 


\section{SUMMARY}

A computer program has been written to solve the modified Millington and Quirk equation for computing the hydraulic conductivity curve for partially saturated soil from the moisture retention versus suction measurements. This document describes the equation and computer programs. It also shows plots of test results and compares them with physically measured data. 
$\underline{\text { Page }}$

SUMMARY. . . . . . . . . . . . . . . . . . . . . iii

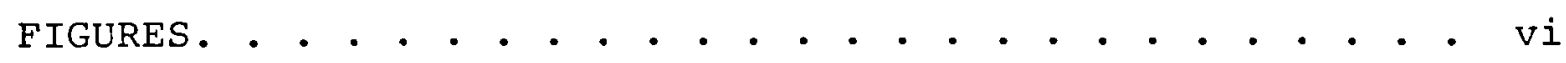

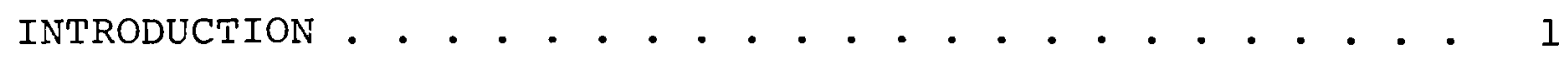

MATHEMATICAL DEVELOPMENT AND COMPUTER PROGRAM. • • . . • • 3

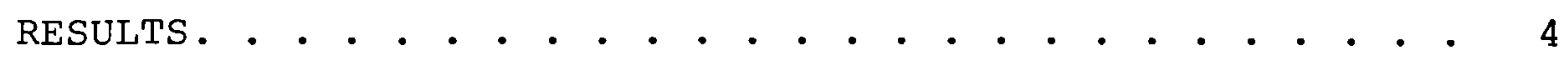

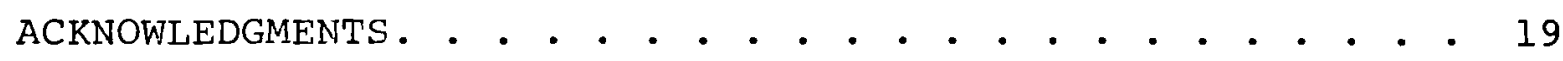

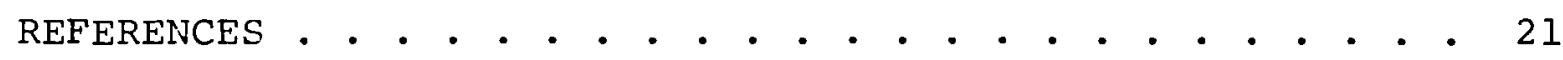

APPENDIX A - USER'S MANUAL . . . . . . . . . . . . . . A-1

APPENDIX B - COMPUTER PROGRAM LISTINGS . . . . . . . . . . B-1 


\section{FIGURES}

Figure

Page

1 Water Potential Versus Water Content Relationship for Pachappa Loam. . . . . . . . 6

2 Computed and Measured Hydraulic Conductivity Versus Water Potential for Pachappa Loam. . . • . 7

3 Water Potential Versus water Content Relationship for GE No. 2 Sand. . . . . . . . 8

4 Computed and Measured Hydraulic Conductivity Versus Water Potential for GE No. 2 Sand. . . . . . 9

5 Water Potential Versus water Content Relationship for Touchet Silt Loam. . . . . . 10

6 Computed and Measured Hydraulic Conductivity Versus Water Potential for Touchet Silt Loam. • • 11

7 Particle Size Distribution for Touchet silt Loam and GE No. 2 Sand. . . . . . . . . . . 12

8 Hydraulic Conductivity Versus suction Head for the Lysimeter Soil. . . . . . . . . . . . . 13

9 Water Content Versus Suction Head for the Lysimeter Soil. . . . . . . . . . . . . . . 14

10 Hydraulic Conductivity Versus Suction Head for the "A" Tank Farm Soil. . . . . . . . . . . 15

11 Water Content Versus Suction Head for the "A" Tank Farm Soil. . . . . . . . . . . . . 16

12 Hydraulic Conductivity Versus Suction Head for a Typical Clay Soil . . . . . . . . . . 17

13 Water Content Versus Suction Head for a Typical Clay Soil. . . . . . . . . . . . . . 18 


\section{CALCULATION OF SOIL HYDRAULIC CONDUCTIVITY FROM SOIL-WATER RETENTION RELATIONSHIPS}

\section{INTRODUCTION}

Although rigorous theoretical descriptions of water movement in porous media have been developed in recent years, flow of water in unsaturated porous media is particularly complex and its mathematical description is difficult. The development of numerical methods and modern high-speed computer equipment permits application of the theoretical principles of flow to these complex systems, which include unsaturated flow beneath intermittent streams, waste cribs, leaking tanks or pipelines, and agricultural irrigation. Fundamental to the solution of a boundary value problem in unsaturated flow in porous media is an adequate description of the hydraulic conductivitysuction relationship and the water content-suction relationship for each soil involved.

Available experimental measurement methods for the hydraulic conductivity-suction relationship are both time-consuming and difficult.1,2 These involve use of a soil column fitted with tensiometers in which liquid flow is induced by incrementally increasing the negative pressure in the liquid phase. With each decrease in pressure, the column flow must adjust to steady-state conditions prior to recording the hydraulic conductivity at that potential. The problem of holding good soil tensiometer contact at increasingly lower pressures restricts most measurements of this type to the wetter end of the scale. The difficulty of obtaining satisfactory data has been a major deterrent to solving many problems.

Several investigators, recognizing the problem of satisfactorily evaluating the hydraulic conductivity-water suction relationship, have developed procedures for calculating the hydraulic conductivity from the more easily measured water content-suction data. $3,4,5,6$ These methods have recently been reviewed by Bruce 7 who found that in all cases the technique for calculating the hydraulic conductivity assumes (1) that the pore system contributing to the flow over the desired range of moisture content is adequately modeled and (2) that the moisture content-suction relationship provides adequate data. The accuracy of the results depends to some degree on how well the model fits the real system. There are also conflicting reports in the literature about the accuracy of the data used in the comparison with calculated data.8,9,10,11,12 The conclusion drawn by both Bruce ${ }^{7}$ and Jackson 8 after testing several other methods was that the Millington and Quirk 5 method with a matching factor gave the best and most reliable results. On the basis of these investigations, this method was adopted for use in this program. 
This document describes the mathematical equation for calculating the hydraulic conductivity-suction relationship from moisture content versus suction measurements and the computer program written to solve the equation. A manual for using the program is included as Appendix A. These calculations are used as input to the Partially Saturated Transient Groundwater Flow Model (BNWL-1713) which was developed for the Radionuclides in Soils program. The role of the hydraulic conductivity calculation in relation to other components of the Radionuclides in Soils program is depicted in the schematic diagram below.

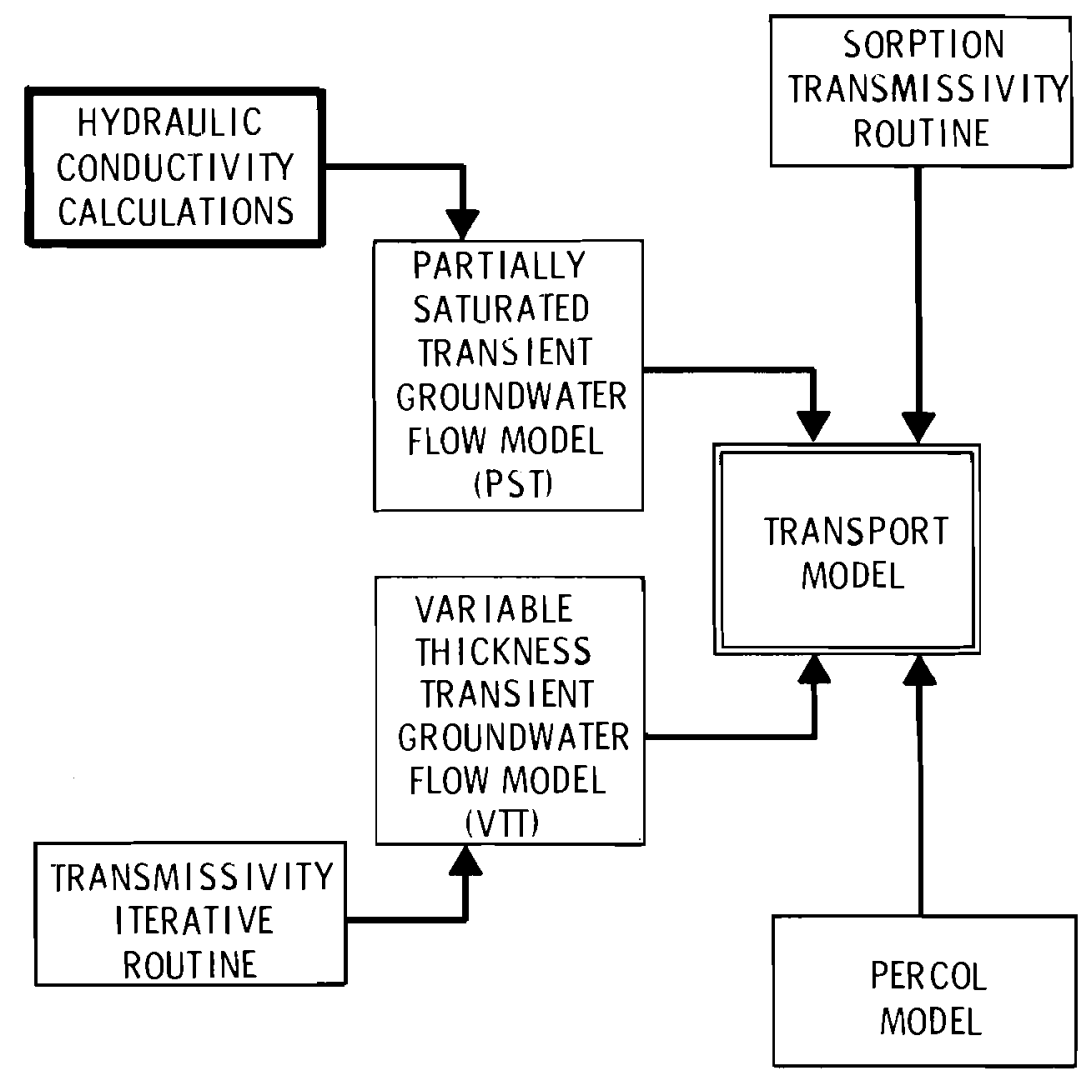

HYDROLOGICAL MODELING PROGRAM COMPONENTS 
The method originally presented by Millington and Quirk ${ }^{5}$ with a matching factor introduced by Jackson can be written as:

$$
\begin{aligned}
K(\theta)_{i} & =\frac{k_{s} 30 \gamma^{2} \theta^{4 / 3}}{k_{s c}(\rho g \eta) n^{2}} \sum_{j=i}^{n}[(2 j+1-2 i)]_{j}^{1 / 2} \\
i & =1,2 \ldots . . n
\end{aligned}
$$

where

$$
\begin{aligned}
\mathrm{K}(\theta)_{i} & =\begin{array}{c}
\text { calculated conductivity for a specified } \\
\text { moisture content or pressure class }(\mathrm{cm} / \mathrm{min})
\end{array} \\
\mathrm{K}_{\mathrm{S}} / \mathrm{K}_{\mathrm{SC}} & =\begin{array}{r}
\text { matching factor (measured saturated conductivity/ } \\
\text { calculated saturated conductivity) }
\end{array} \\
\gamma & =\text { surface tension of water (dynes/cm) } \\
\mathrm{g} & =\text { gravitational constant }\left(\mathrm{cm} / \mathrm{sec}^{2}\right) \\
\eta & =\text { water viscosity }(\mathrm{gm} / \mathrm{cm}-\mathrm{sec}) \\
\theta & =\text { water-filled porosity }\left(\mathrm{cm}^{3} / \mathrm{cm}^{3}\right) \\
\mathrm{n} & =\text { total number of pore } \mathrm{classes} \\
\mathrm{h} & =\text { pressure, suction head }(\mathrm{cm}) \\
\rho & =\text { density of water }
\end{aligned}
$$

The first term of the equation contains the matching factor $\mathrm{K} / \mathrm{K}$ and a group of constants which convert the hydraulic conductivity to units of $\mathrm{cm} / \mathrm{min}$ and the pore radius to pressure potential (h) in millibars, both at a temperature of $27^{\circ} \mathrm{C}$. The constants $30 \gamma^{2} / \rho g \eta$ convert to a value of $1.884 \times 10^{4}$.

The computer program used to solve Equation 1 was written in standard Fortran IV for the Univac 1108. The output from the program is normally a set of punched cards and two calcomp plots, one showing the calculated hydraulic conductivity- 
suction relationship and the other the moisture content-suction relationship interpolated from the input data. Only the nearsaturated part of these curves is plotted. The program makes of an interpolation technique known as Aitken's interpolation formulal3, 44 which is used to obtain values of moisture content and suction at specified even increments of moisture content. A four-point interpolation is used which requires that the original data be hand-smoothed to obtain satisfactory results.

\section{$\underline{\text { RESULTS }}$}

Two sets of results are shown in Figures 1 through 12 . The first set was done to show the validity of the method for a range of soil material. Included here are Pachappa Loam, G.E. 2 sand, and Touchet silt Loam. The second set includes three recently sampled soils; one from an experimental lysimeter facility located south of 200 East Area, a soil collected from an excavation north of the 200 East "A" tank farm, and a typical Ringold clay, all from the Hanford Reservation. Table 1 shows the primary data for each soil.

TABLE 1. Saturated Hydraulic Conductivity and Porosity for Six Soils

$\begin{array}{llc} & \begin{array}{c}\text { Saturated Hydraulic } \\ \text { Conductivity }\end{array} & \text { Porosity } \\ \text { Pachappa Loam } & 1.2 \times 10^{-2} \mathrm{~cm} / \mathrm{min} & .456 \\ \text { Touchet Silt Loam } & 1.8 \times 10^{-3} \mathrm{~cm} / \mathrm{min} & .496 \\ \text { G.E. 2 Sand } & 6.77 \times 10^{-1} \mathrm{~cm} / \mathrm{min} & .330 \\ \text { Lysimeter Soil } & 7.0 \times 10^{-1} \mathrm{~cm} / \mathrm{min} & .270 \\ \text { "A" Tank Farm Soil } & 1.6 \times 10^{-2} \mathrm{~cm} / \mathrm{min} & .372 \\ \text { Clay } & 1 \times 10^{-6} \mathrm{~cm} / \mathrm{min} & \end{array}$

$K($ Darcy $)=\mathrm{am}_{\mathrm{m}} / \mathrm{sec}$ 
The computer program was used to calculate the hydraulic conductivity function from measured volumetric water content and potentials. The data points on Figures 1 and 2 were taken from the literature. Figure 1 shows the water content-water potential for the Pachappa Loam; the points are measured values on the desorption curve. Figure 2 compares the computed hydraulic conductivity curve with measured point values. This is the only soil for which a measurement has been made below -1 x 10-5 millibars of water potential. Figure 3 shows the saturation-potential curve as described from the measured points for G.E. 2 Sand, a surface sample from near the 200 East Area patrol headquarters. Figure 4 shows the computed hydraulic conductivity-potential curve and compares it with points measured by King. 1 Figure 5 shows the measured point of saturation-potential and the curve for Touchet silt Loam used to calculate the hydraulic conductivitypotential curve shown as a line in Figure 6. The measured values, by King, I are plotted as points on the graph. The Touchet silt Loam is representative of soil from Cold Creek Valley near Rattlesnake Mountain. Figure 7 shows the particle size distribution visually indicating the finer texture of the Touchet soil.

Figures 8 through 13, outputs from execution of the computer program, represent recently sampled soils for which no hydraulic conductivity values below that of saturation have been measured. Figure 8 shows the computer calculated hydraulic conductivity curve versus the potential or suction head in millibars for the lysimeter soil. The points are computer generated from water content versus suction head curve shown in Figure 9. Figure 10 shows the hydraulic conductivity-suction head curve for the "A" tank farm soil as computed from the water content-suction head curve presented in Figure 11. Figure 12 shows the hydraulic conductivity curve as computed from the water content-suction head (Figure 13) for a typical Hanford clay soil. 


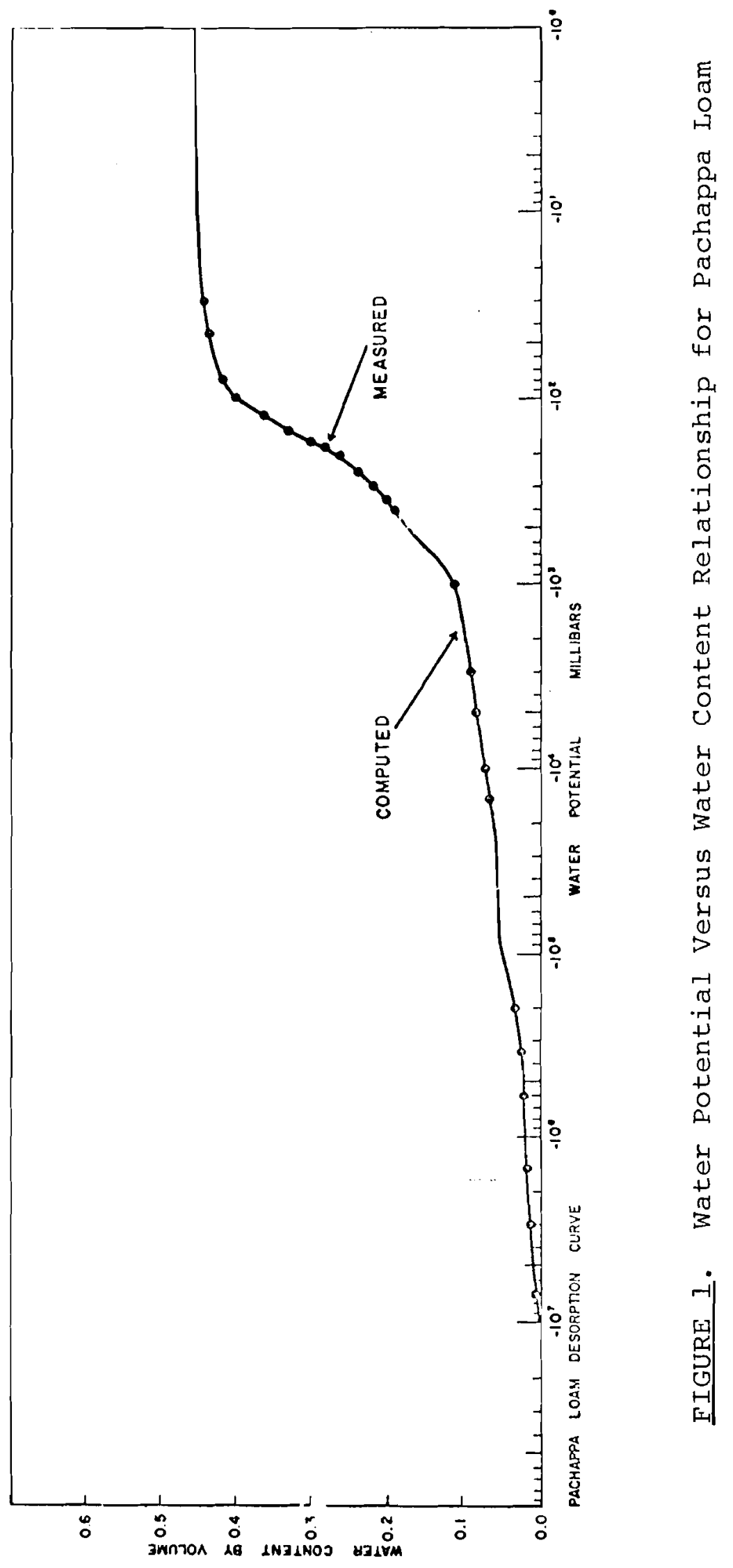




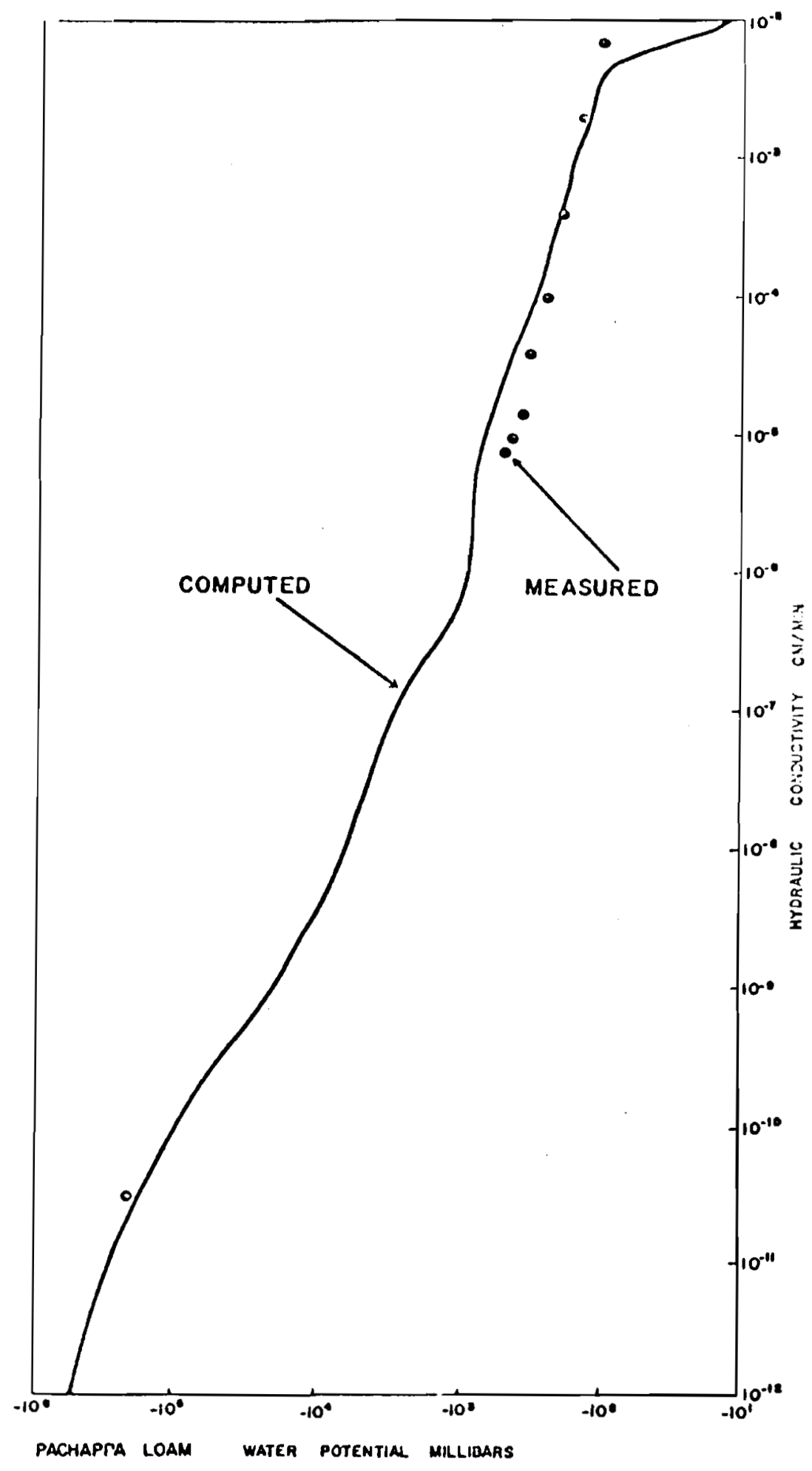




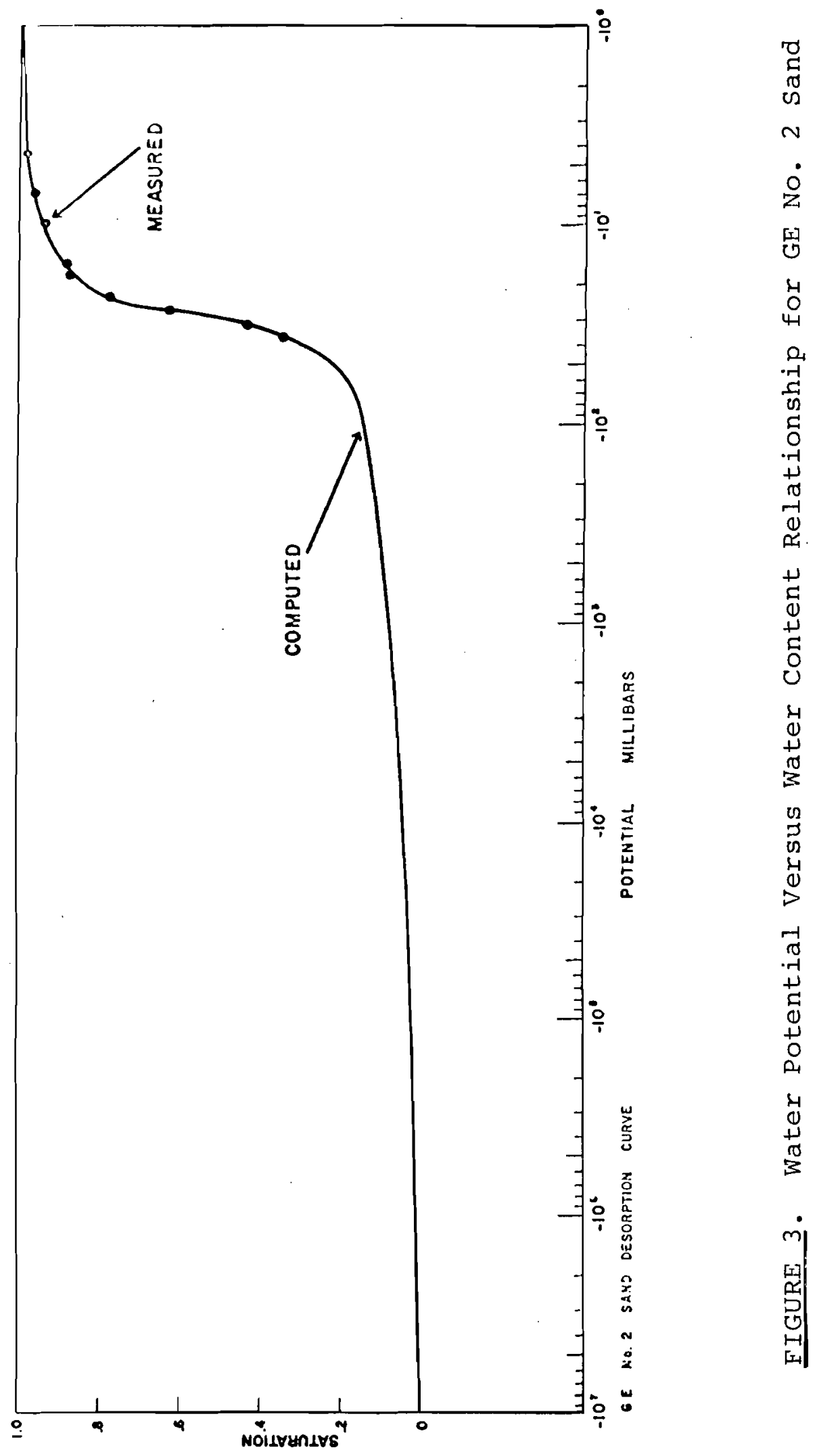




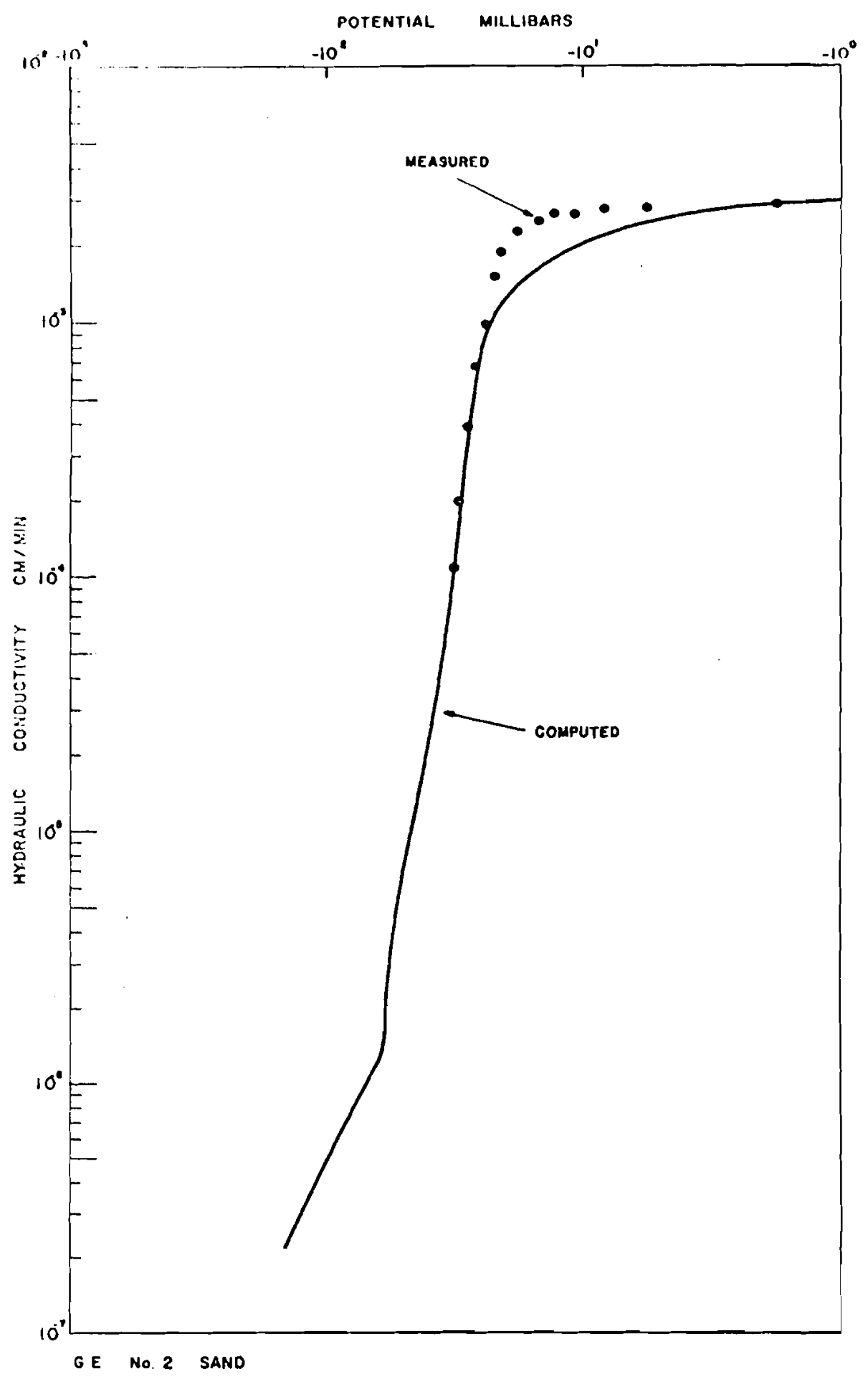




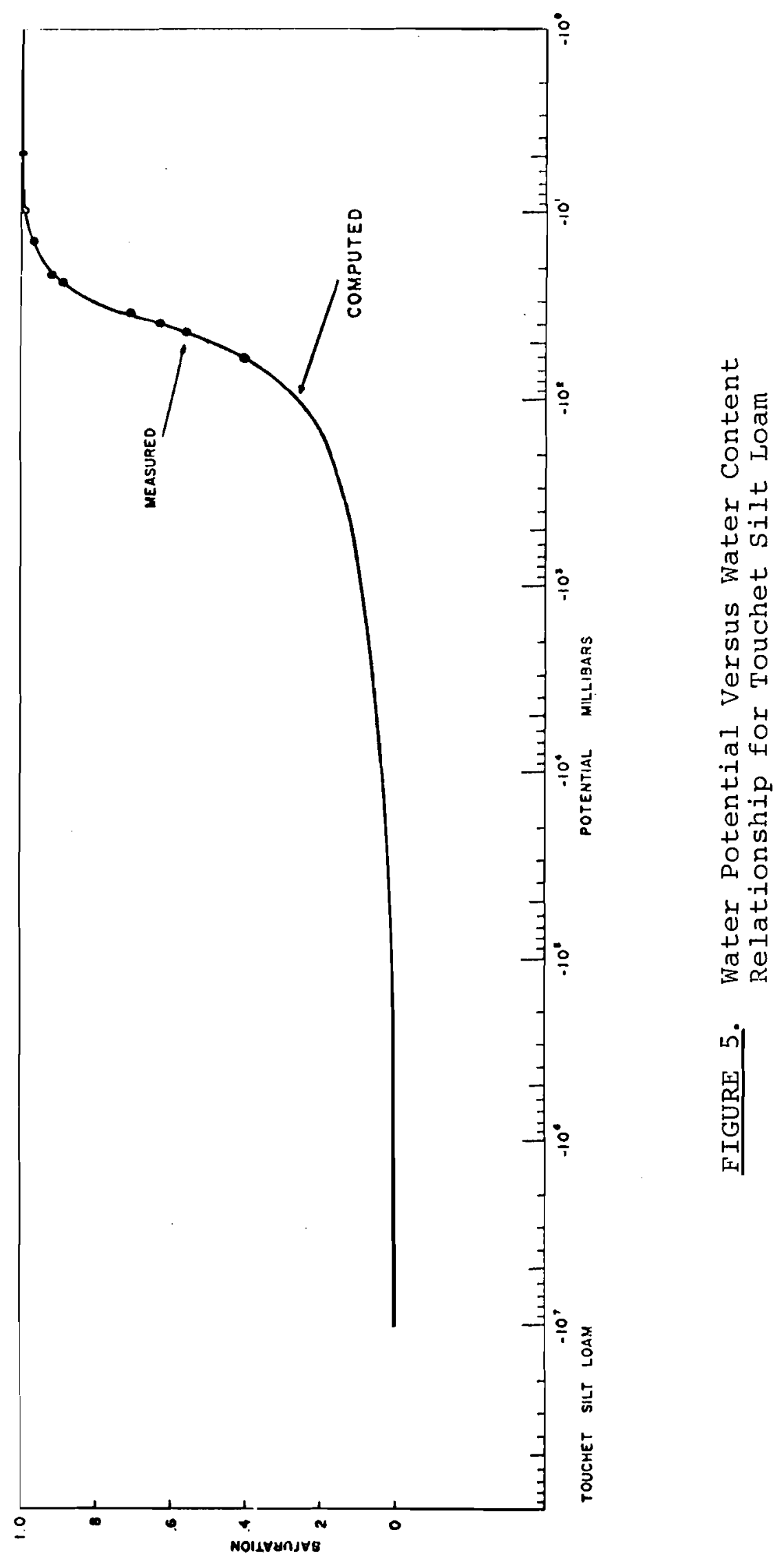




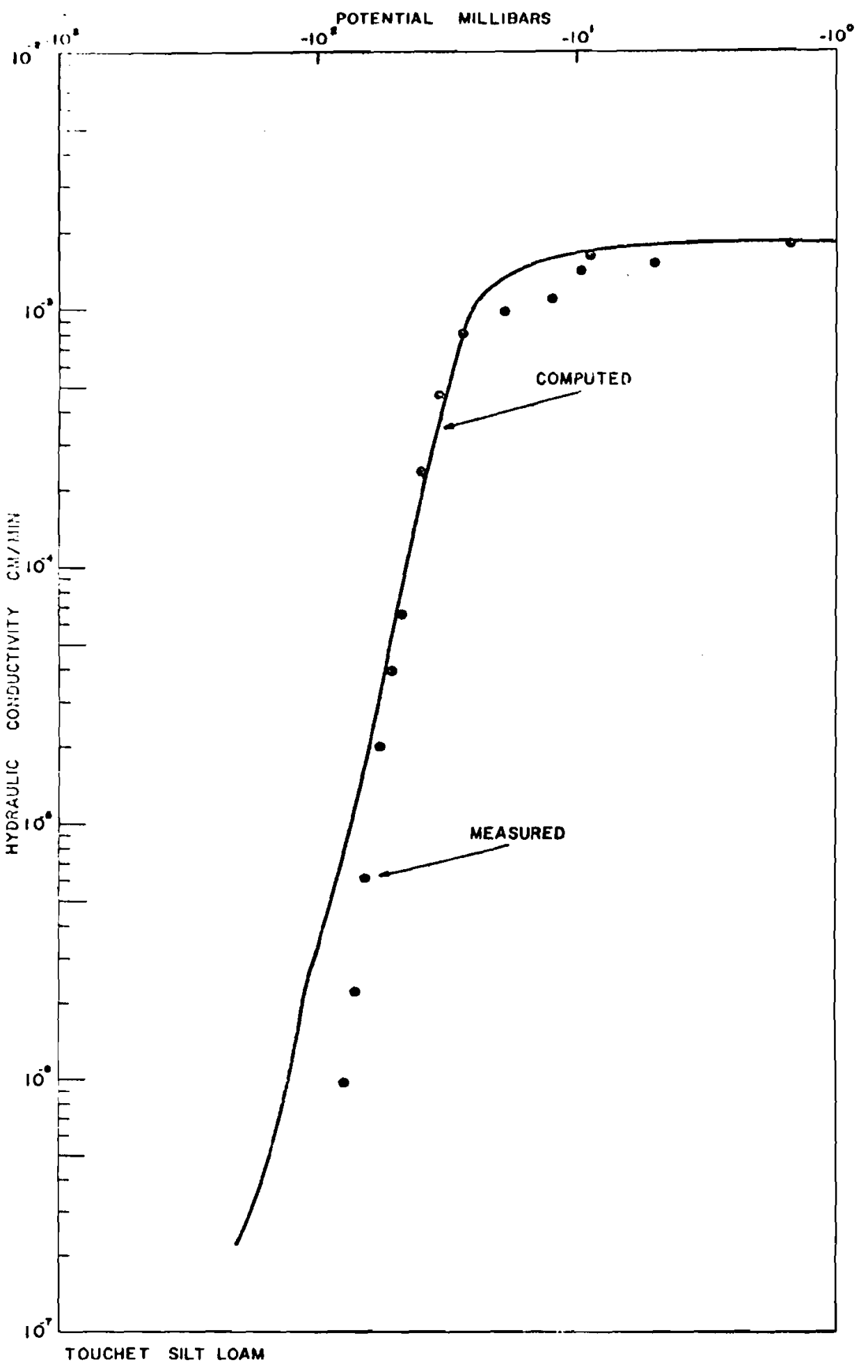

FIGURE 6. Computed and Measured Hydraulic Conductivity Versus Water Potential for Touchet Silt Loam 


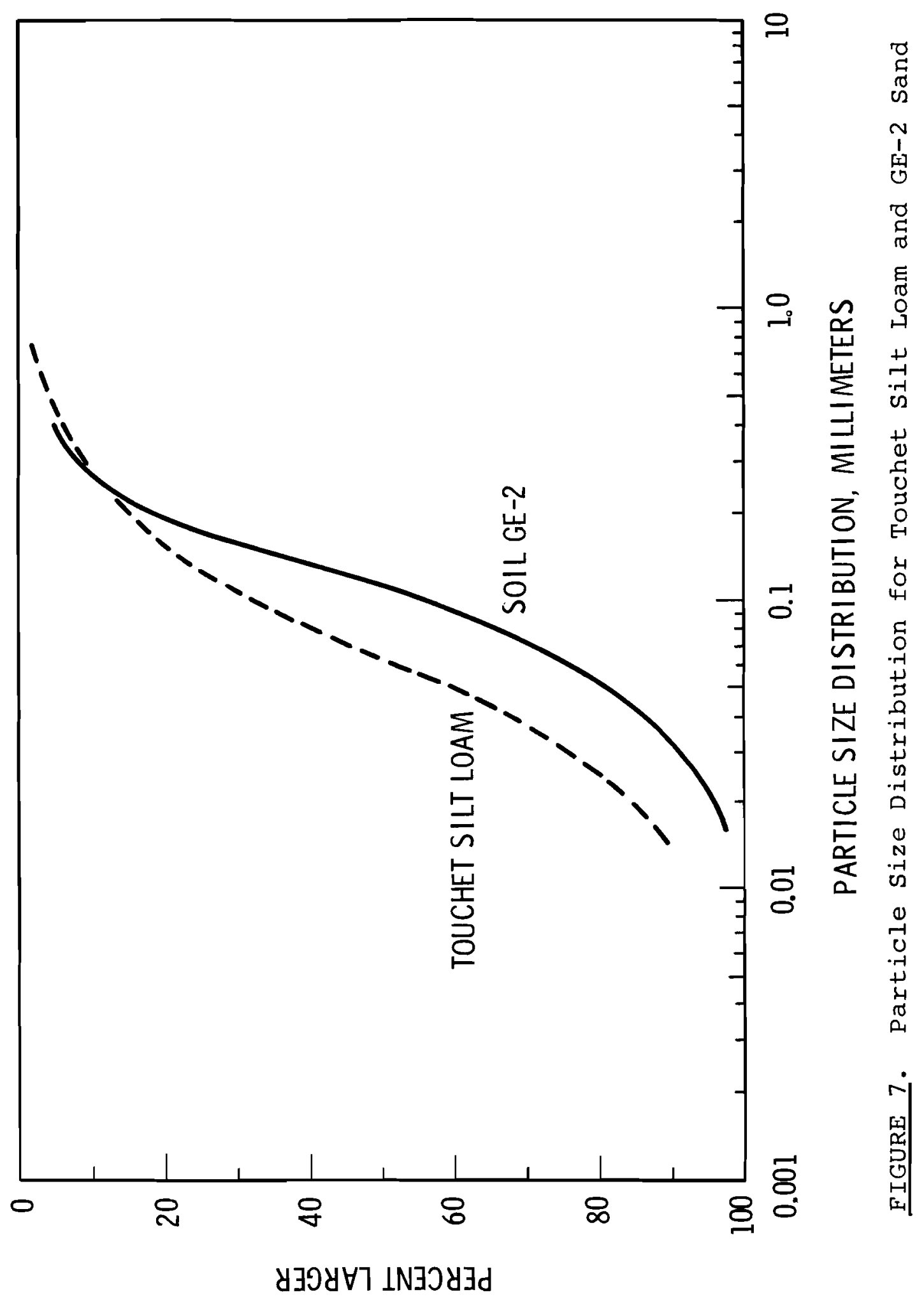




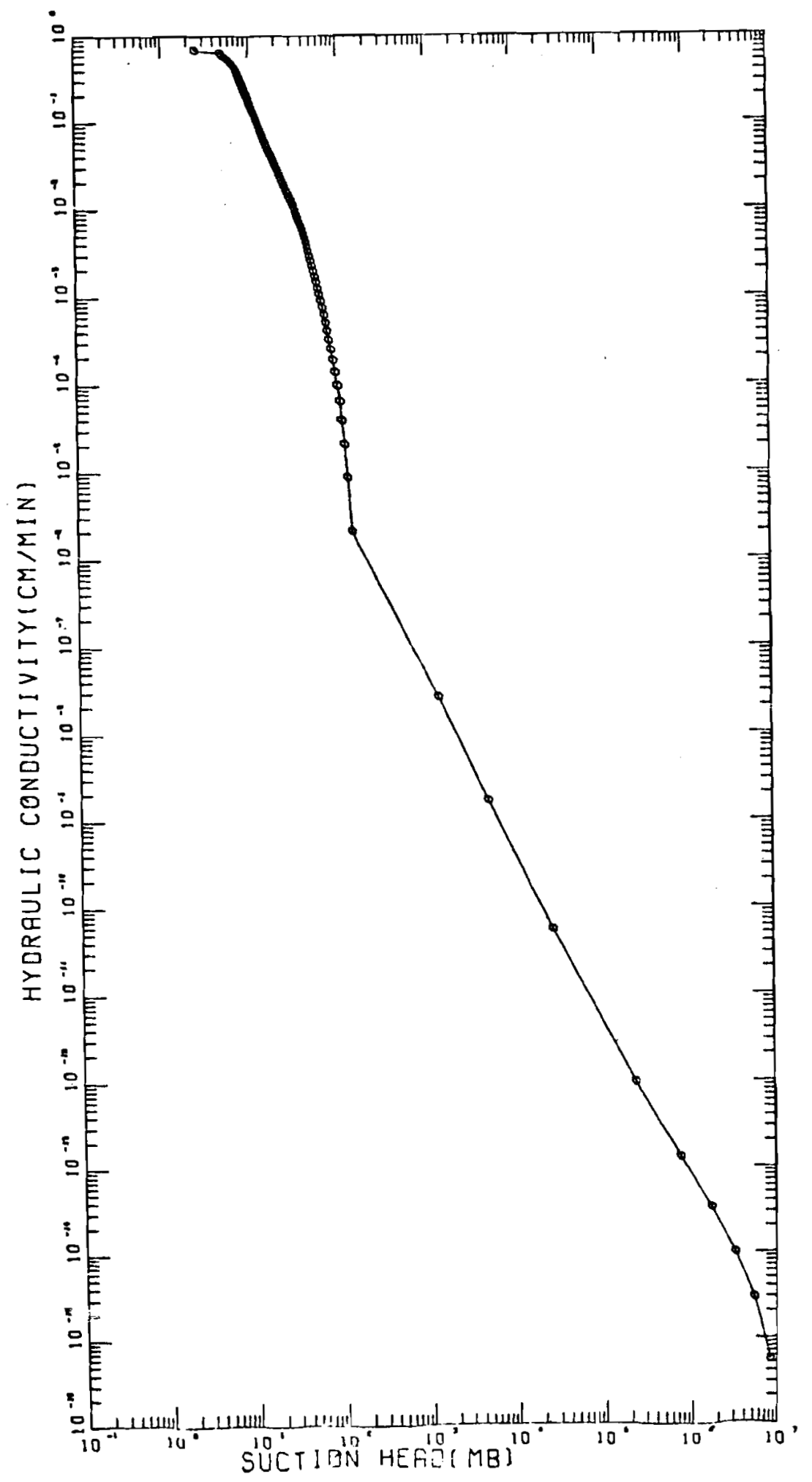

FIGURE 8 . Hydraulic Conductivity Versus suction Head for the Lysimeter Soil 


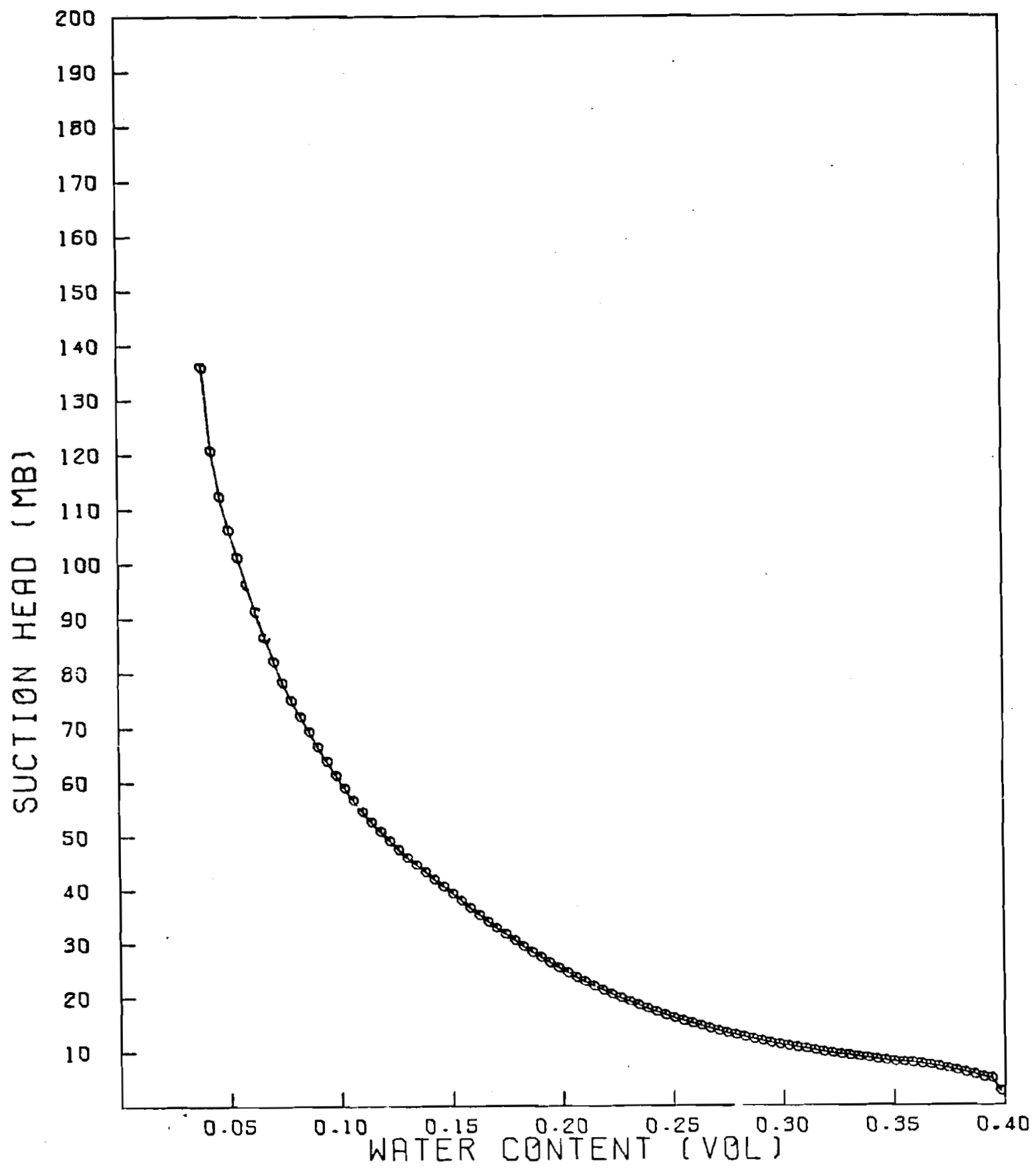

FIGURE 9. Water Content Versus Suction Head for the Lysimeter soil 


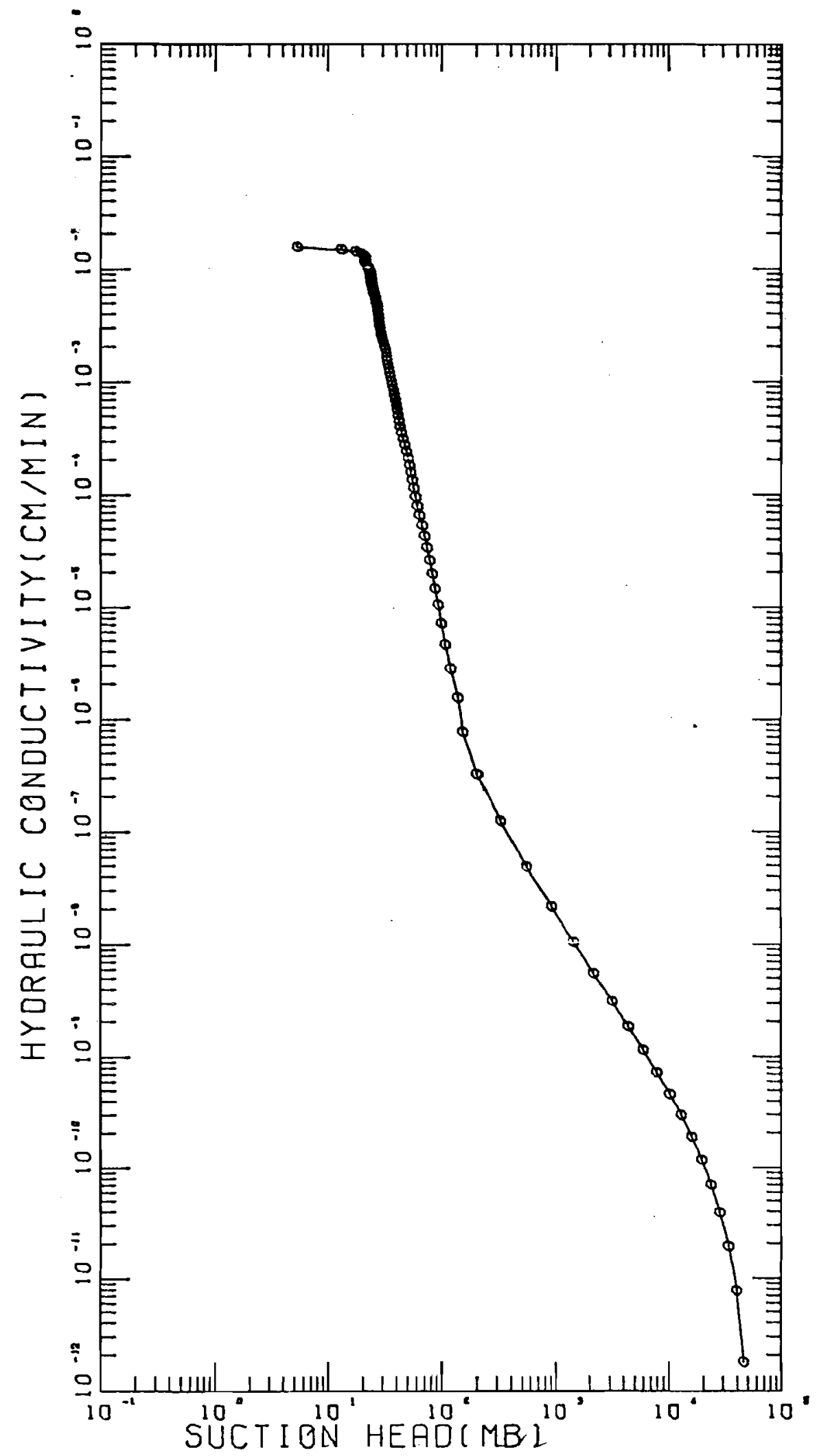

FIGURE 10. Hydraulic Conductivity Versus Suction Head for the "A" Tank Farm Soil 


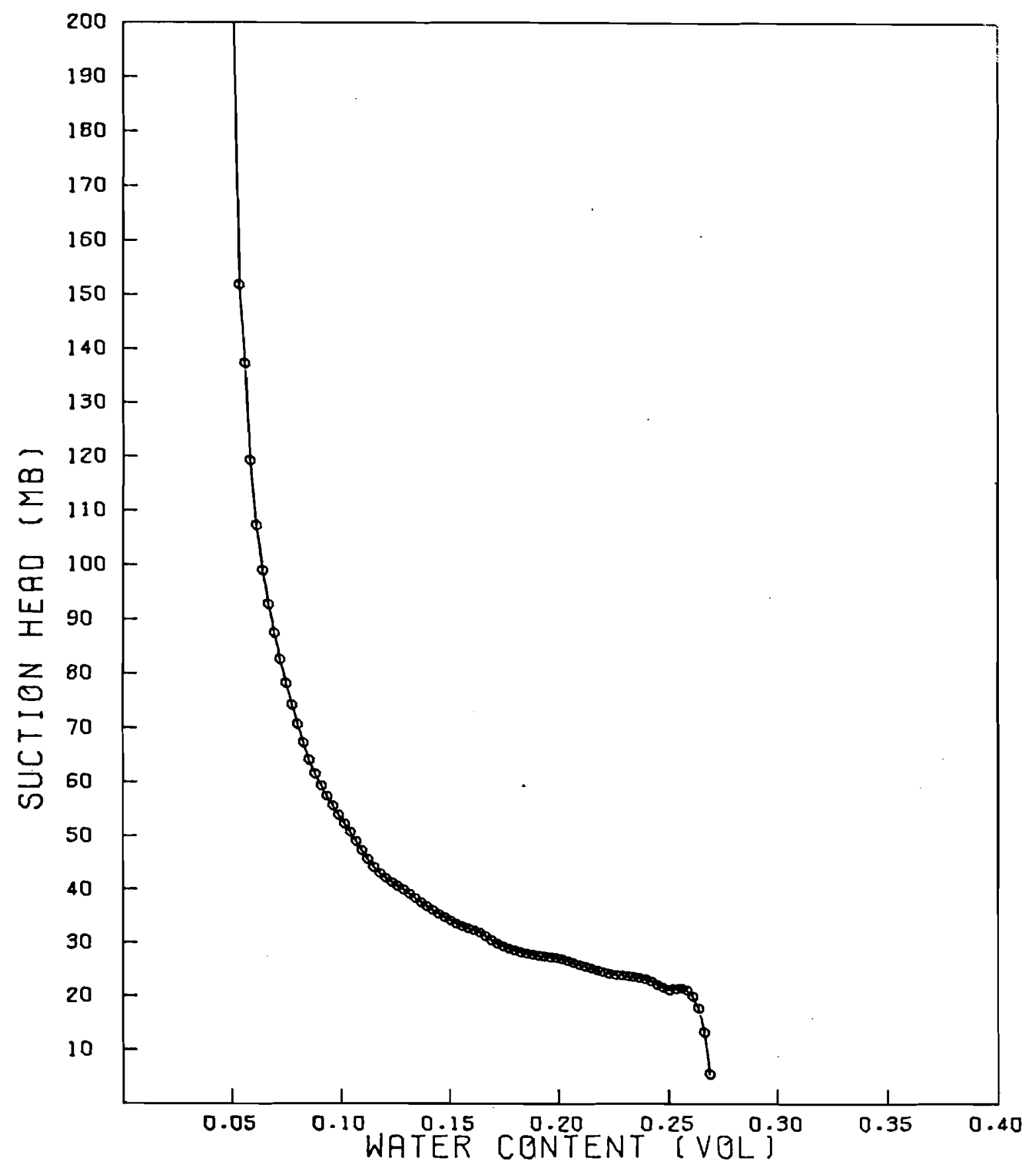

FIGURE 11. Water Content Versus Suction Head for the "A" Tank Farm Soil 


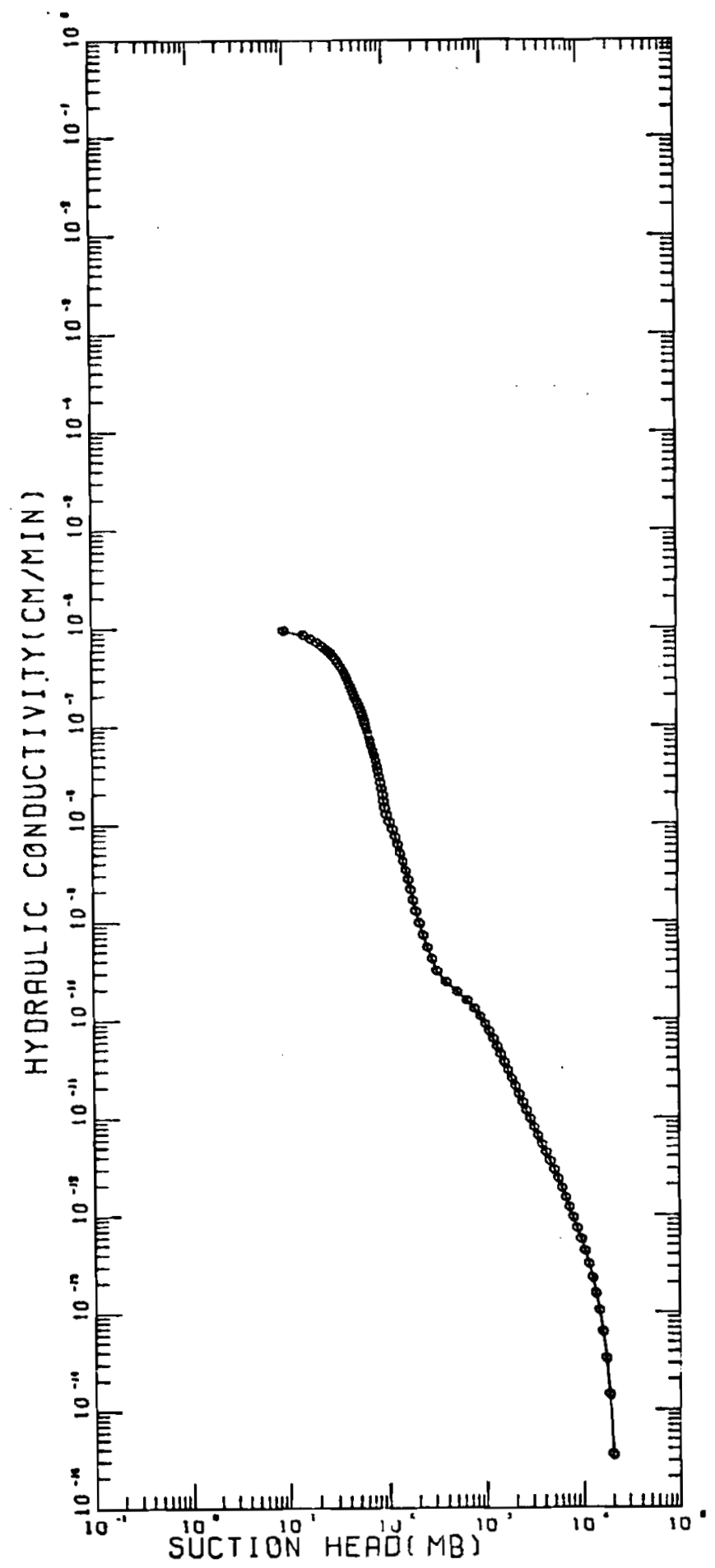

FIGURE 12. Hydraulic Conductivity versus suction Head for a Typical Clay Soil 


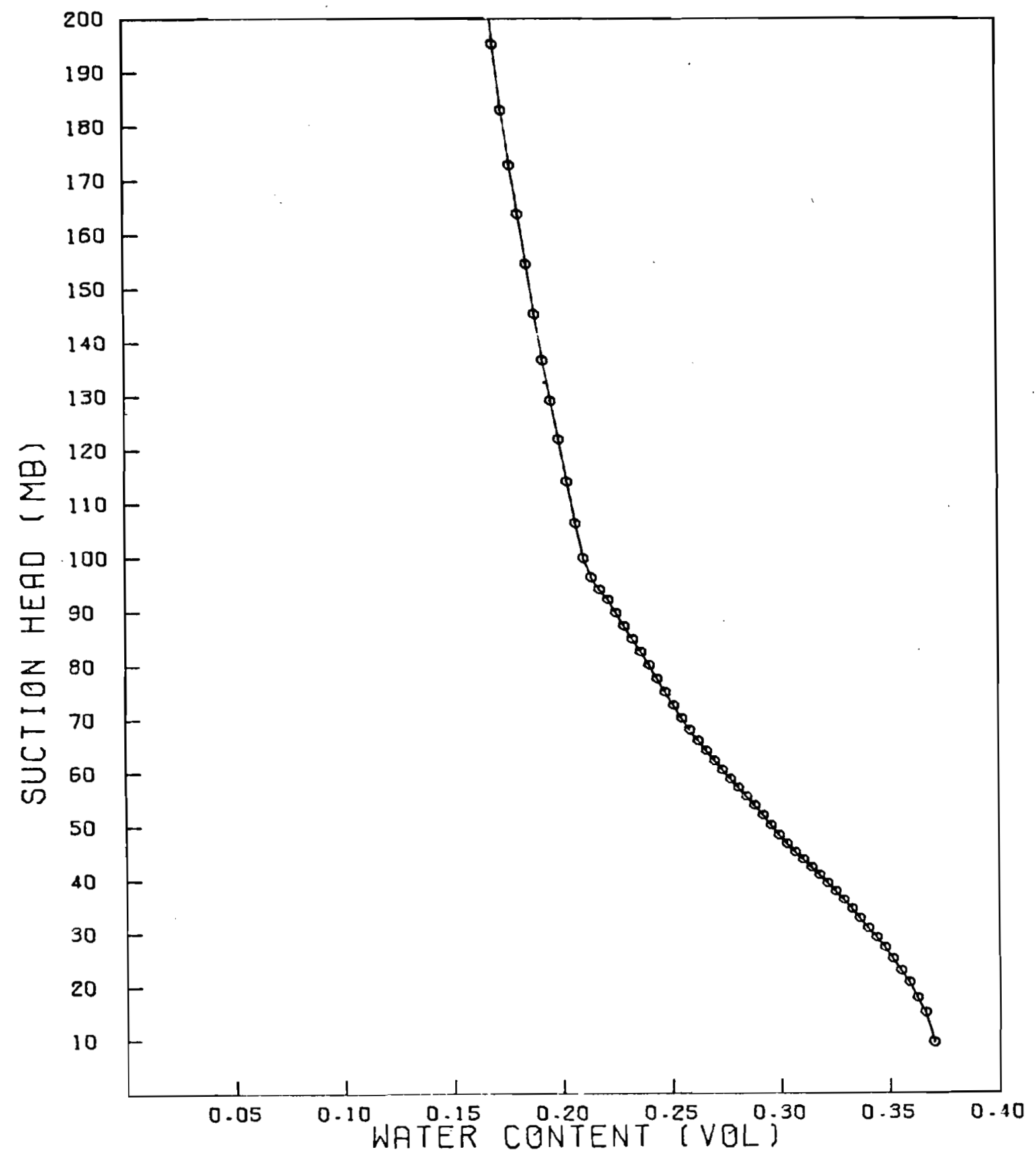

FIGURE 13. Water Content Versus Suction Head for a Typical Clay Soil 


\section{ACKNOWLEDGMENTS}

This research was sponsored by the Advanced Technology Development Section, Research and Development Department, Atlantic Richfield Hanford Company. The authors are grateful for the assistance and direction provided by Dr. M. D. Veatch, Staff Hydrologist; D. J. Brown, Staff Geologist; and R. E. Isaacson, Manager of the Advanced Technology Development Section of Atlantic Richfield Hanford Company.

The efforts of Leila Counts, who provided editorial assistance, and Jan Greenwell, Loretta Howard and Velva Harris, who typed the many drafts and final reports, are also greatly appreciated. 
APPENDIX A

USER'S MANUAL 


\section{REFERENCES}

1. King, L. G., "Imbibition of Fluids by Porous Solids." Unpublished Ph.D. dissertation. Colorado State University, Ft. Collins, Colorado, 1964.

2. Brooks, R. H. and A. T. Corey, "Hydraulic Properties of Porous Media." Hydrology Paper No. 3, Colorado State University, Ft. Collins, Colorado, 1964.

3. Childs; E. C. and N. Collis-George, "The Permeability of Porous Materials." Royal Soc. (London) Proc. A201:392-405, 1950 .

4. Marshall, T. J., "A Relations Between Permeability and Size Distribution of Pores." Jour. Soil Sci., 9:1-8, 1958.

5. Millington, R. J. and J. P. Quirk, "Permeability of Porous Solids." Trans. Faraday Soc. 57:1200-1207, 1961.

6. Laliberte, G. E., A. T. Corey and R. H. Brooks, "Properties of Unsaturated Porous Media." Hydrology Paper No. 17, Colorado State University, Ft. Collins, Colorado, 1966.

7. Bruce, R. R., "Hydraulic Conductivity Evaluation of the Soil Profile from Soil Water Retention Relations." Soil Sci. Amer. Proc. 36:555-560, 1972 .

8. Jackson, R. D., R.J. Reginato and C. H. M. van Bavel, "Comparison of Measured and Calculated Hydraulic Conductivities of Unsaturated Soils." Water Resources Res. $1: 375-380,1965$.

9. Kunze, R. J., G. Uchara and K. Graham, "Factors Important in the Calculation of Hydraulic Conductivity." Soil Sci. Soc. Amer. Proc. 32:760-765, 1968.

10. Nielsen, D. R., Don Kirkham and E. R. Perrier, "Soil Capillary Conductivity: Comparison of Measured and Calculated Values." Soil Sci. Soc. Amer. Proc. 24:157-160, 1960.

11. Shaykewich, C. F., "Hydraulic Properties of Disturbed and Undisturbed Soils." Can. Jour. Soil Sci. 50:431-437, 1970.

12. Green, R. E. and J. C. Corey, "Calculation of Hydraulic Conductivity: A Further Evaluation of Some Predictive Methods." Soil Sci. Soc. Amer. Proc. 35:3-8, 1971.

13. Aitken Interpolation, Univac 1107 Math Pack, Section 2, pp. 55-59.

14. Hildebrand, F. B., Introduction to Numerical Analysis. McGraw-Hill Book Company, 1956. 


\section{USER'S MANUAL}

Use of the computer program requires data for a measured saturated hydraulic conductivity, a measured porosity, and a measured set of water content-suction data through which a smooth best-fit curve has been drawn. The water contentsuction data are normally obtained using pressure plate extraction apparatus for the very high negative pressure range and tensiometer manometer measurements on the soil sample at the lower negative pressures near the saturated end of the curve. A good definition of the curve near saturation is needed. From this curve a set of data points is chosen which adequately describes the curve.

The program input consists of the number of input data points chosen from the water content-suction curve, the number of pore classes or points at which a hydraulic conductivity calculation will be made, the list of data points, the saturated hydraulic conductivity, and the porosity of the soil.

The program output lists the input values, followed by a table showing hydraulic conductivity, water content, percent saturation, suction head, and relative permeability. Punched cards with the suction head, the relative permeability, and the percent saturation are produced. A log-log plot of the hydraulic conductivity versus suction head and the water content versus suction head is produced for the near saturated part of the curve. A plot of water content versus capillary pressure is also output.

The input to the program consists of three different card types:

Card 1 contains two fields of five-column integers (2I5).

$$
\begin{aligned}
& \text { Field A - Number of input points of moisture } \\
& \text { content. }
\end{aligned}
$$

Field B - Number of output points interpolated from input points.

Card 2 contains two floating point fields (2F10.0).

$$
\begin{gathered}
\text { Field A - Contains negative pressure value } \\
\text { (suction in millibars). } \\
\text { Field B - Contains the corresponding moisture } \\
\text { contents. }
\end{gathered}
$$


$\mathrm{N}$ number of Type 2 cards will be necessary to complete this list. The points must be in monotonically increasing order of moisture content.

Card 3 contains two floating point fields (2F10.0).

Field A - Contains the saturated hydraulic conductivity.

Field B - Contains the porosity. 
APPENDIX B

COMPUTER PROGRAM LISTINGS 


\section{APPENDIX B}

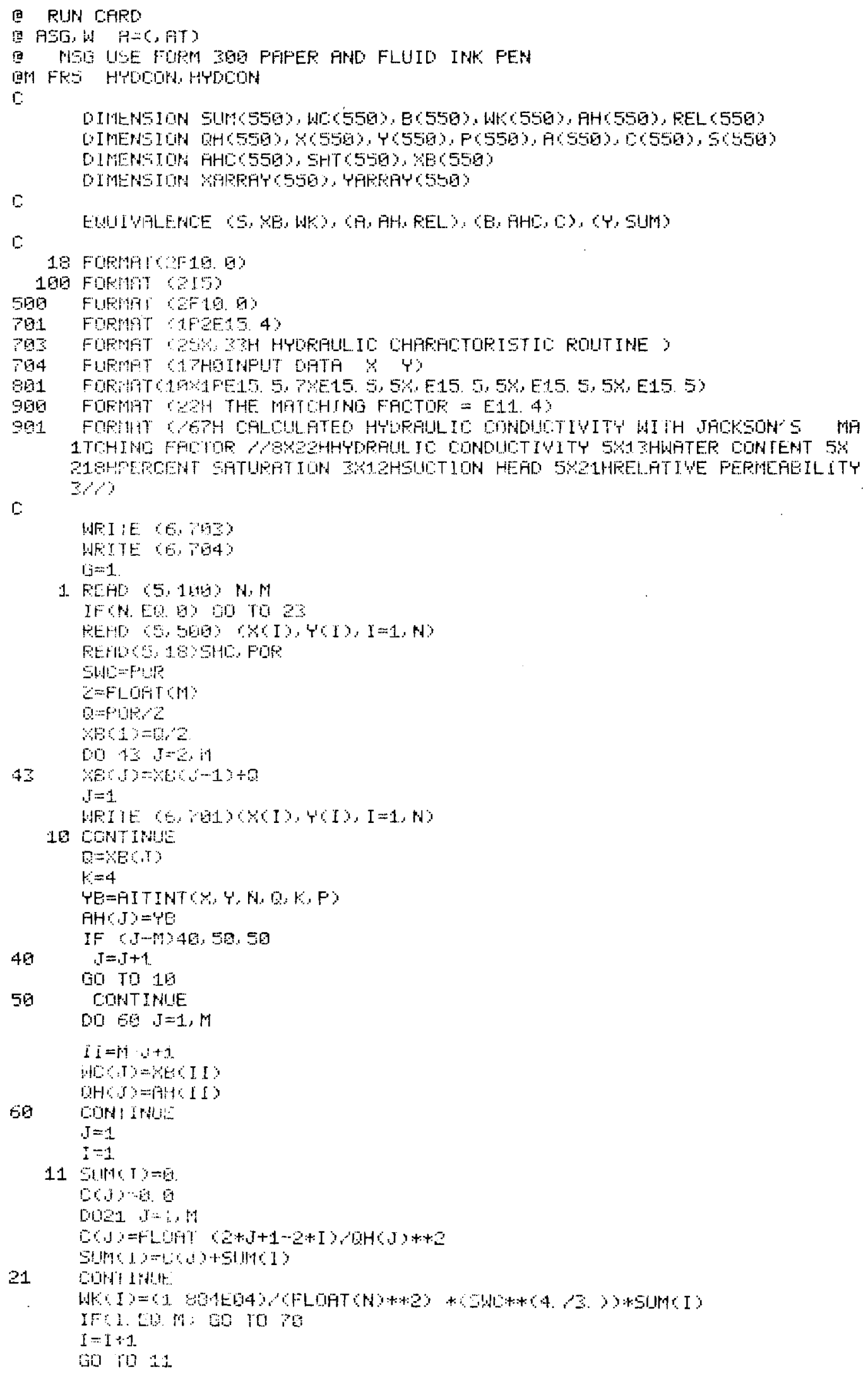


DOURT IANJE

(10) $82 \mathrm{I}=1, \cdots$

I I $=11-1+1$

ACIY-HICCII)

82

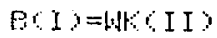

LOHAT I R⿴囗十

T'E=HIT I I I (A, B, M, SWE, K, P)

CSOHL= ${ }^{\prime \prime} \mathrm{E}$

TIF $=\mathrm{SHL}, \mathrm{OH}$

WFITE (6, 900) TMF

$00 \quad 1 \vec{i} \quad I=1.11$

HHC I I = THF t+ Whe I )

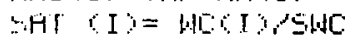

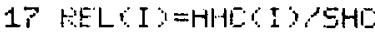

APITE (E. 9G1)

का $20 \quad i=i, 1$

LPI IE(T, EHA) FHC(I), HC(I), SAT (I), QH(I), REL(I)

$1 \mathrm{HT}=-\mathrm{DSH} \mathrm{I}$ ?

PURAL 7 OHT, RELSI) SAT (I)

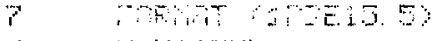

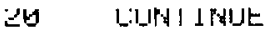

EFLL DFLOT CAHC, DH, KAFEAY, YAREAY, MY

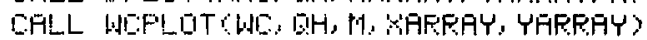

150 TO 1

23 GOMAT I NUE

ERLL CFLOT CE, 9, 9. 9, 999?

CALL EXIT

END

ION FRS DPLOT. OPLOT

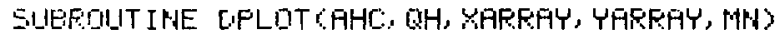

[:

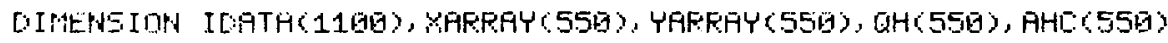

E

c

PG FORMAT CLFE15. 4 \%

ERLI CPLDTSC IDFTA(1), 1160,1)

$|+|+\mid$

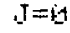

C D ENTER W ANO Y YALIJES FOR FLUT

C. C DISLAED Ald' NELJATIVE VALUES

Do $25 \quad I=1$. mad

$26 \quad \mathrm{~J}=\mathrm{J}+1$

IF $6 \mathrm{I}$. EQ $(M N+1)$ OII TI 22

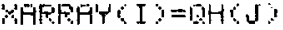

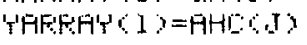

$I I=I$

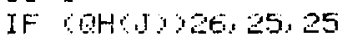

25 LOCNTT INIIE

25 OONTIHAE

[n] $2 \% \quad H=1$. I I

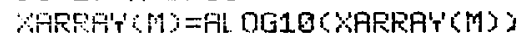

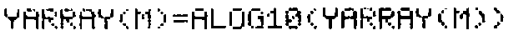

$k=1+1$

27 GINTINUE

c.

C GHLLLILAT EOUNOARIES FOR $X$ AND Y RWIS

$K K=M F F H(1)$

$K K=K K-1$

$\mathrm{I}_{\mathrm{T}} \mathrm{T}=\mathrm{TAERTSC}$ I I

$J, J=4, J \cdots 1$

MH = MAFTHY (I)

$|+1|=|\cdot| 1+1$

$L L=I A E S$ CKK) $+M M$ 


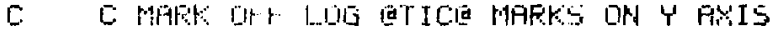
[0] $106101 . \mathrm{JJ}$

1 bi,$y=1+1$

IFU FO AHET TO 100

$Z^{\prime} T^{\prime}=5$ thit $(A)$

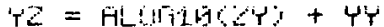

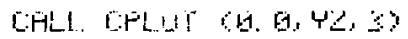

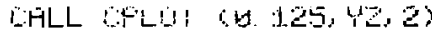

CHLL LELUICHYS YZZ

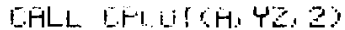

IFCI. L. 199070161

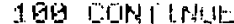

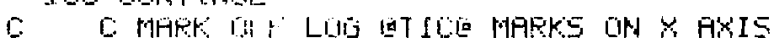

LII $2 \mathrm{BA}, 1-1, \mathrm{LL}$

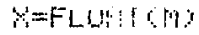

CFLL LPLUT \& $6.9,3$

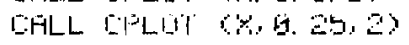

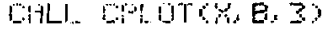

LFILL GHLTSO ER. 2 ?

$n=1$

$\left.x_{1}=F=0+1+1\right)$

$201 N=N+1$

IF CN. EO 19) 100 TO 209

$Z X=F L A T(N)$

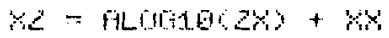

EFLL EPLOT $(42,0.0,3$

CFLL CFLUT $\% 2,0.125,2)$

GFLL CFLUT(AE, B, 3)

GHLL OFLOTHE, BS 2

IFG. L.T. 1 b) Go TO 201

200 COAT IHUE

c

E. PUMPER 'T'

$J J=J, J+1$

DI) $3019 \mathrm{I}=1, \mathrm{~J} \mathrm{~J}$

$Z=$ FLOATCI $5-1.05$

$\mathrm{T} z=z+8.321$

$Y Z Y=F L T H A T(I-T M)$

CALL PNMER (-0. 10, 2, 0. 125, 10. 0, 90. 9, -1)

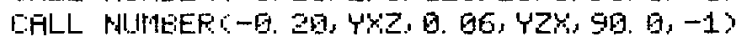

3 Gg CINAT INUE 


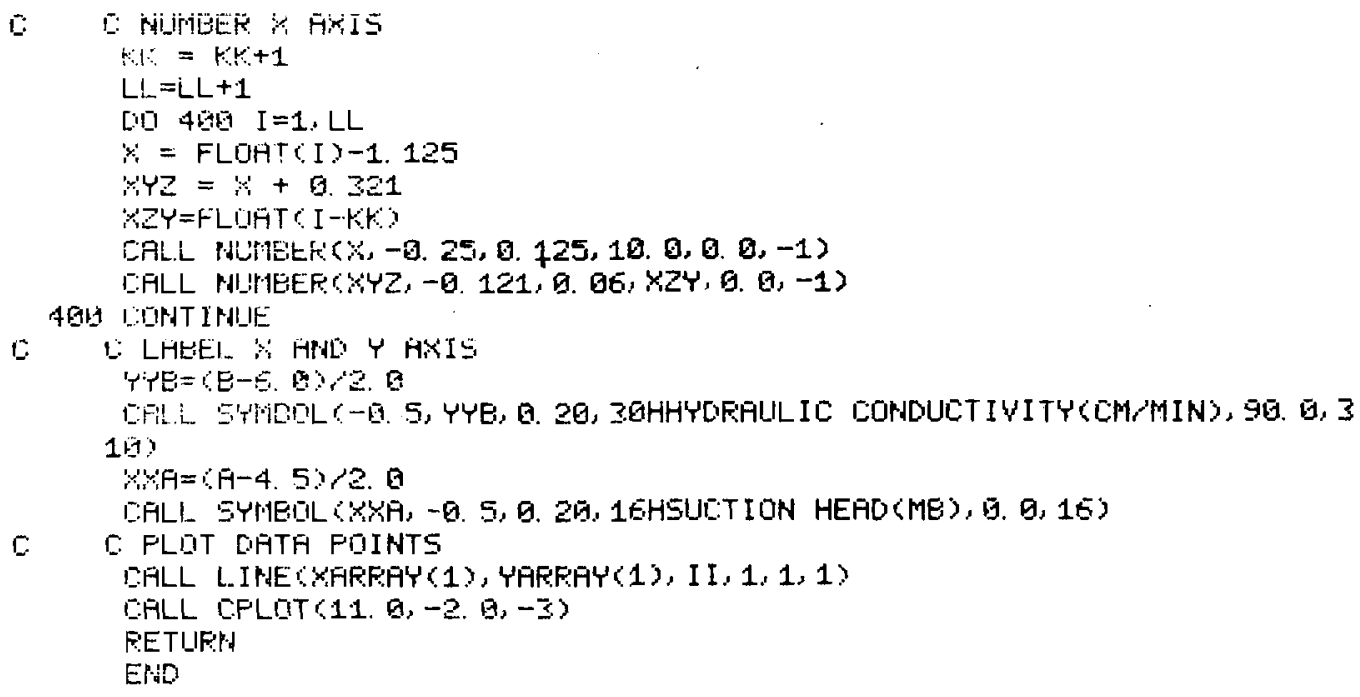




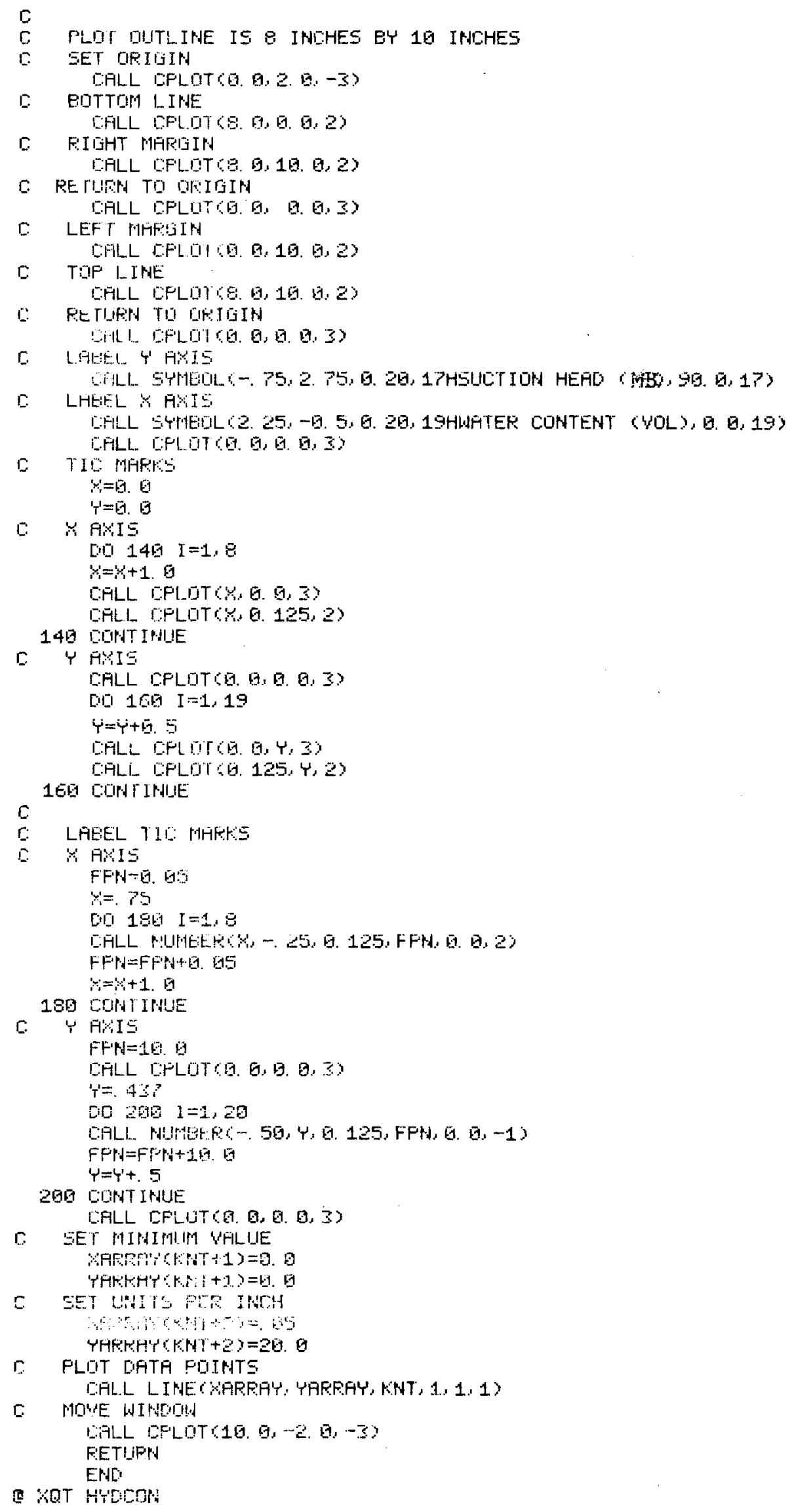




\section{DISTRIBUTION}

No. of

Copies

1

201

2

2

2

2
Off-site

AEC Chicago Patent Group

G. H. Lee

AEC Technical Information Center

Atomic Energy Commission Headquarters Waste Management and Transportation Germantown, Maryland 20767

Owen P. Gornley

Chief, waste Facilities Branch

Robert W. Ramsey, Jr.

Chief, Development Branch

Atomic Energy Commission Site Safety

Division

Directorate of Regulation

7920 Norfolk Avenue

Bethesda, Maryland 20014

Ronald L. Bullard

Chief, Environmental Specialist Branch

W. Gamill

Chief, Site Analysis Branch

Atomic Energy Commission

Division of Production \& Material Management Washington, D. C. 20545

William L. Lennemann

Chief, Chemical Process

James W. Pollock

Atomic Energy Commission

Idaho Falls, Idaho 83401

Dr. Adrian H. Dahl

Chief, Environmental Science Branch

B. L. Schmalz

Distr-1 
No. of

Copies

U. S. Geological Survey

2100 M. Street

Washington, D. C. 20037

George Debuchananne, Director

M. K. Hubbert

Research Geophysicist

Dallas Peck

U. S. Geological Survey

Menlo Park, California 94025

Jacob Rubin

1

U. S. Geological Survey

Groundwater Branch

Denver, Colorado

R. W. Stallman

1

U. S. Geological Survey

Water Resources Division

Bldg. 53, Room H-2910

Lakewood, Colorado 80225

J. D. Bredehoeft

1

U. S. Geological Survey

Water Resources Division

P.O. Box 917

Council Bluffs, Iowa 51501

O. J. Ramsvick

Supervisory Hydrologist

1

U. S. Geological Survey

Albuquerque, New Mexico

Dr. C. V. Theis

1

U. S. Geological Survey

Water Resources Division

P.O. Box 2857

Raleigh, North Carolina

Ralph C. Heath

District Chief

Distr-2 
No. of

Copies

Off-site

2

U. S. Bureau of Mines

4800 Forbes Avenue

Pittsburgh, Pennsylvania 15213

George Evans

Robert W. Van Dolah

3

U. S. Bureau of Mines

Spokane Mining Research Laboratory

N. 1430 washington st.

Spokane, Washington 99201

Robert C. Bates

Dan Keeley

Michael M. McDonald

1

U. S. Forestry Service

Intermountain Forest and Range Experiment station

Boise, Idaho 83702

Dr. Walter F. Meghan

Research Hydrologist

1

Environmental Protection Agency

Crystal Mall

Washington, D. C. 20460

Arnold Joseph

1

Environmental Protection Agency

office of Research \& Monitoring

Edison Water Quality office

Edison, New Jersey 08817

Richard Field

1

National Water Commission

$800 \mathrm{~N}$. Quincy

Arlington, Virginia 22209

Dr. John S. Gladwell

1

USDA-ARS

U. S. Water Conservation Laboratory

4331 East Broadway

Phoenix, Arizona 85040

Dr. Herman Bouwer

Hydraulic Engineer 
No. of

Copies

Off-Site

1

USDA-ARS

U. S. Salinity Laboratory

P.O. Box 672

Riverside, California 92502

Dr. Jan Van Schilfgaarde, Director

1

USDA-ARS

Engineering Research Center CSU Foothills Campus

Fort Collis, Colorado 80521

Dr. David A. Woolhiser

Hydraulic Engineer

1

USDA-ARS

Northwest watershed Research Center P.O. Box 2700

Boise, Idaho 83701

Walter J. Rawls, Hydrologist

1

USDA-ARS

P.O. BOX 1096

Boise, Idaho 83701

J. L. Robins

1

USDA-ARS

Twin Falls, Idaho

M. E. Jensen

1

USDA-ARS

Snake River Conservation Research Center Route 1, Box 186

Kimberly, Idaho 83341

Dr. Marvin E. Jensen, Director

1

USDA Hydrograph Laboratory

Plant Industry station

Soils Building

Beltsville, Maryland 20705

H. N. Holton, Director

1

USDA-ARS

Plant Industry station

Beltsville, Maryland 20705 
No. of

Copies

Off-Site

Dr. Donald L. Brakensick

Chief Engineer

1

USDA Sedimentation Laboratory

P.O. BOX 30

Oxford, Mississippi 38655

A. R. Robinson, Director

1

USDA-ARS

Southern Region

Stoneville, Mississippi 38776

John C. Stephens, Director

1

USDA-ARS

North Central Watershed Research Center P.O. Box 916

Columbia, Missouri 65201

Dr. C. R. Amerman

Hydraulic Engineer

1

USDA-ARS

North Appalachian Experimental Watershed Coshocton, Ohio 43812

Dr. W. M. Edwards

Soil scientist

1

USDA

P.O. Box 400

Chickasha, Oklahoma 73018

Harry B. Pionke

1

USDA-ARS

Northeast watershed Research Center

Pennsylvania state University

111 Research Building 3

University Park, Pennsylvania 16802

Dr. A. S. Rogowski

Soil Scientist

National Academy of Science

U. S. National Committee for the IHD 2101 Constitution Avenue

Washington, D. C. 20418

Dr. Leo Heindl

Executive Secretary 
No. of

Copies

Off-Site

1

National Academy of Science

Committee on Radioactive Waste Management

National Research Council

2101 Constitution Avenue

Washington, D. C. 20418

Dr. Cyrus Klingsberg

Technical Secretary

1

National Science Foundation

Division of Advanced Technology Application 1800 6th street N.W.

Washington, D. C. 20530

Ray Zahradnik

1

U. S. Naval Civil Engineering Laboratory

Port Hueneme, California 93043

Dr. James J. Der

2

Robert S. Kerr Water Research Center

P.O. BOX 1198

Ada, Oklahoma 74820

Dr. J. W. Keeley

Marion R. Scalf

1

Alabama Geologic Survey

P.O. Drawer O

University, Alabama 35486

Phil Lammereaux

State Geologist

1

Southwest Rangeland Watershed Research

Center

442 E. Seventh Street

Tucson, Arizona 85705

Dr. R. Smith

1

California Dept. of Water Resources

Helen J. Peters 
No. of

Copies

1

Off-Site

Idaho Bureau of Mines \& Geology

University of Idaho

Moscow, Idaho 83843

Dr. Roy E. Williams

1

Idaho Dept. of Water Administration State House, Annex 2

Boise, Idaho 83707

Keith R. Higginson, Director

1

Idaho Water Resources Board

Boise, Idaho

R. R. Lee

1

Illinois state water Survey

P.O. Box 232

Urbana, Illinois 61801

Keros Cartwright

1

State Geological Survey of Kansas

University of Kansas

Lawrence, Kansas 66044

Dr. John C. Halepaska

Chief, Water Resources Section

1

State of Maine

Environmental Improvement Commission

Augusta, Maine 04330

Steven D. Freedman

1

st. Anthony Falls Hydraulic Laboratory Mississippi River at 3rd Avenue East Minneapolis, Minnesota 55414

Professor C. Edward Bowers

2

Desert Research Institute

Center for water Resources Research

Reno, Nevada

Dr. Clinton Case

G. B. Maxey 
No. of Copies

1

1

1

1

1

1

1

1
Off-Site

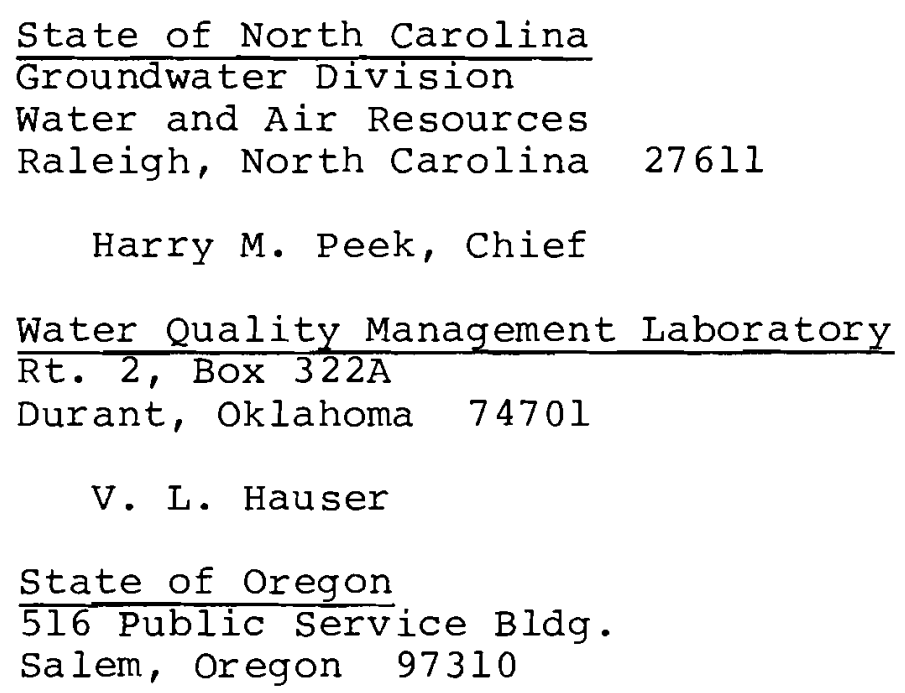

State of North Carolina Groundwater Division Water and Air Resources Raleigh, North Carolina 27611

Harry M. Peek, Chief

Water Quality Management Laboratory Rt. 2, Box 322A

Durant, Oklahoma 74701

V. L. Hauser

State of Oregon 516 Public Service Bldg. Salem, Oregon 97310

Chris Wheeler State Engineer

Texas Water Development Board Systems Engineering Division P.O. Box 13087

Austin, Texas 78711

Lial F. Tischler

Agencies for Environmental Conservation Montpelier, Vermont 05602

Dr. Martin L. Johnson Secretary

State of Washington

Department of Ecology

P.O. Box 829

Olympia, Washington 98504

John R. Raymond

Washington State Water Research Center Pullman, Washington 99163

James Crosby, III

Geologist

Atomic Industrial Forum, Inc. 475 Park Avenue South New York, New York 10016

Gerald V. Halvorsen

Environmental Projects Manager 
No. of

Copies

1

1

1

1

1

1

1

1

2
Off-Site

$$
\begin{aligned}
& \text { Computer Sciences Corp. } \\
& \text { Federal Building } \\
& \text { Richland, Washington } 99352 \\
& \quad \text { R. W. Nelson }
\end{aligned}
$$

Sandia Laboratories

Division 5166

Albuquerque, New Mexico

87115

Fred Norwood

Arthur M. Piper

\#3 Sonoma Lane

Carmel, California 93921

Alyeska Pipeline Service Co. 2100 Travis street

Houston, Texas 77002

Dr. Maurice D. Veatch

E. I. duPont deNemours \& Co., Inc.

Savannah River, South Carolina

J. C. Corey

University of Arizona

Office of Arid Lands Studies

1201 East Speedway Blvd.

Tucson, Arizona 95719

Dr. Ken Faster

University of Arizona

Dept. of Agriculture Chemistry and soils Tucson, Arizona 85721

Dr. Gordon Dutt

University of Arizona

Dept. of Hydrology and water Resources

200-E Old Psychology

Tucson, Arizona 95721

Dr. A. K. Tyagi

Dr. Chester C. Kisiel 
No. of

Copies

Off-site

2

University of Arizona

Tucson, Arizona 95721

E. S. Simpson

A. W. Warrick

2

University of California

Berkeley, California 94720

Dr. Warren Kauffman

P. A. Witherspoon

Dept. of Civil Engineering

3

University of California at Davis Dept. of Water Sciences and Engineering Davis, California 95616

J. N. Luthin

Don Nielson

Dr. Verne H. Scott

1

University of California at Riverside college of Biological \& Agricultural Sciences

Riverside, California 92507

Dr. N. T. Coleman

3

Stanford University

Department of Civil Engineering

stanford, California 94305

Paul Kruger

Henry J. Ramey

J. B. Franzini

1

Stanford University

School of Earth Sciences

Dept. of Geology

Stanford, California 94305

E. Aguado

Distr -10 
No. of

Copies

1

1

2

1

1

1

1

1
Off-site

Georgia Institute of Technology School of Civil Engineering

Atlanta, Georgia 30332

Dr. J. R. Wallace

University of Idaho

Moscow, Idaho 83843

Dr. Delbert Fitzsimmons

Head, Agricultural Engineering

University of Illinois

Urbana, Illinois 61801

A. Klute

Professor Ven Te Chow

Hydrosystems Laboratories

Purdue University

Dept. of Agricultural Engineering

Wast LaFayette, Indiana 47907

Emru D. Millette

Iowa State University

Ames, Iowa

D. Kirkham

University of Kansas

Water Resources Institute

Lawrence, Kansas 66044

Don W. Green

University of Kentucky Department of Mechanical Engineering Lexington, Kentucky 40506

$$
\text { C. T. Hahn }
$$

Harvard University

School of Public Health

Boston, Massachusetts 02138

Dr. D. W. Moeller

Distr-11 
No. of

Copies

Off-Site

1

Massachusetts Institute of Technology

77 Massachusetts Avenue

Room 48-263

Cambridge, Massachusetts 02139

Dr. Donald Harleman

1

University of Minnesota

Department of Geology and Geophysics

2D Pillsbury Hall

Minneapolis, Minnesota 55455

Hans olaf Pfannkuch

1

University of Minnesota

Department of Civil Engineering

Minneapolis, Minnesota 55418

H. Steforn

2

University of Nebraska

School of Civil Engineering

Lincoln, Nebraska 68503

Mark J. Hammer

Warren Viessman, Jr.

1

Princeton University

School of Engineering/Applied Science

Department of Civil and Geological

Engineering

Princeton, New Jersey 08540

Dr. Robert W. Cleary

2

Princeton University

Department of Civil \& Geological

Engineering

Princeton, New Jersey 08540

R. J. M. DeWiest

G. F. Pinder

1

New Mexico State University

Department of Agronomy

P.O. BOX 3Q

Las Cruces, New Mexico 88001

P. J. Wierenga 
No. of

Copies

$\underline{\text { Off-site }}$

1

State University of New York at Buffalo Dept. of Mechanical Engineering

Buffalo, New York 14214

Ralph T. Cheng

1

State University of New York Dept. of Civil Engineering

Buffalo, New York 14214

Dr. Ralph Rumer

2

Cornell University

School of Civil Engineering B22 Bailey Hall

Ithaca, New York 14850

W. H. Brutsaert

Winton Covey

2

Oregon State University

Corvalis, Oregon 97331

Dr. Larry Boersma

Professor of Soils

Dr. Royal H. Brooks

Professor of Agricultural Engineering

1

Drexel Institute of Technology

Philadelphia, Pennsylvania 19104

Irwin Remson

1

Vanderbilt University

Nashville, Tennessee 37203

Dr. Frank L. Parker

1

Utah State University

College of Engineering

Dept. of Agriculture and Irrigation

Engineering

Logan, Utah 84321

Dr. L. G. King

Distr -13 
No. of

Copies

1

1

1

1

2

2

1 off-site

Utah State University

Utah Water Research Laboratory

College of Engineering

Logan, Utah 84321

J. Paul Riley

Utah State University

Logan, Utah 84321

Dr. Roland W. Jeppson

Associate Prof. of Civil Engineering

Utah State University

Logan, Utah 84321

C. G. Clyde

University of Wyoming

Laramie, Wyoming 82070

Dr. Paul A. Rechard

Director, Water Resources Research

Institute

Washington State University

Dept. of Civil Engineering

148 sloan Hall

Pullman, Washington 99163

Dr. Donald L. Bender

Dr. David Higgins

Washington State University

Dept. of Agronomy \& Soils

Pullman, washington 99163

Dr. Walter H. Gardner

Dr. Eugene Thompson

Washington State University

Albrook Hydraulic Laboratory

Pullman, Washington 99163

Dr. John F. Orsborn, Head 
No. of

Copies

Off-Site

1

University of Washington

Department of Geology

seattle, Washington 98105

Dr. Howard Coombs

University of Wisconsin

Department of Soil Science

Madison, Wisconsin 53706

W. R. Gardner

P. Saffigna

1

Water Conservation and Irrigation Commission

P.O. Box 20R Royal Exchange Sydney, 2000, Australia

Frans R. Kalf

1

University of New South Wales

School of Civil Engineering

Sydney, Australia

Dr. K. K. Watson

1

Institut für Geophysik

Technische Hochschule

Karlsplatz 13

A-1040 WIEN Österreich

Austria

A. E. Scheidegger

$I$

University of British Columbia

Vancouver, B. C., Canada

Dr. Allen Freeze

Dept. of Mines and Natural Resources

Water Resources Branch

693 Taylor Avenue

Winnipeg 9, Manitoba, Canada

Frank W. Render 
No. of

Copies

1

$\underline{\text { Off-Site }}$

University of Waterloo

Department of Earth Science

Waterloo, ontario, Canada

Richard G. Jackson

1

University of Waterloo

Department of Civil Engineering

Faculty of Engineering

Waterloo, Ontario, Canada

John F. Pickens

1

McMaster University

Department of Civil Engineering

Hamilton, ontario, Canada

Dr. William James

2

Ontario water Resources Commission

135 st. Clair Avenue West

Toronto 7, ontario, Canada

Donald N. Jeffs

Bob Ostry

1

Department of the Environment

4905 Dufferin Street

Downsview, Ontario, Canada

Dr. Aloysius K. Lo

2

Department of the Environment C-244, No. 8 Temporary Bldg. Inland Waters Branch

Ottawa, Canada

R. E. Jackson

Dennis Lawson

1

Institut de Mecanique (I.M.G.)

Domaine Universitaire

B. P. 53

Centre de Tri 38041

Grenoble-Cedex, France

Georges Vachaud 
No. of

Copies

1

Off-Site

M. R. Engineering College

Jaipur-302004, India

Dr. R. D. Verma

Prof. of Civil Engineering

1

University College

Upper Merrion Street

Dublin, 2 Ireland

Dr. James C. I. Dooge

Professor of Civil Engineering

1

3

1

1

1

Department of Mechanical Engineers,

I.I.T. Kharagkur,

S.E. RY, India

R. G. Mokadom

Technion-Israel Institute of Technology Haifa, Israel

J. Bear

Shragga Irmay

Dan Zaslavsky

Agricultural Research Organization

The Volcani Center

The Institute of Soils and Water

P.O.B. 6

Bet Dagan, Israel

Shlomo P. Neuman

Land and Water Development Division

Water Resources \& Development Service

Via Delle Terme Dl Caracalla

ool00-Rome, Italy

R. G. Thomas

Kyoto University

Food \& Agriculture Organization of the UN

Kyoto, Japan

Yoriteru Inoue 
No. of

Copies

1

1

University of Canterbury, N.Z. Dept. of Civil Engineering

Christ Church 1, New Zealand

Bruce W. Hunt

On-Site Hanford

1

7

69

Off-Site

c/o Koninklijke/Shell

Volmerlaan 6

A. M. Schaaps

AEC/Rl Patent Attorney

R. M. Poteat

AEC Richland Operations Office

O. J. Elgert

J. L. Rhoades

P. J. Holsted

E. B. Jackson

P. G. Rhoades

R. B. Goranson

B. J. Melton

Atlantic Richfield Hanford Co.
Explorade En Produktie Laboratorium

Ritswijk (Z.H.), The Netherlands

G. E. Backman

G. L. Borsheim

D. J. Brown

L. E. Bruns

M. H. Campbell

W. M. Harty

R. E. Isaacson

(2)

L. M. Knights

C. W. Malody

B. J. McMurray

M. C. Metz

H. P. Shaw

A. E. Smith

P. W. Smith

W. J. Van Slyke

ARHCO File

G. A. Nicholson 
Westinghouse Hanford Co. HEDL

R. B. Hall

Battelle-Northwest

D. B. Cearlock

J. P. Corley

J. R. Eliason

K. L. Kipp

D. E. Olesen

A. E. Reisenauer

D. D. Tillson

R. C. Routson

R. J. Serne

D. R. Friedrichs

S. W. Ahlstrom

R. G. Baca

A. Brandstetter

R. D. Mudd

R. W. Wallace

J. J. Fuquay

A. J. Shuckrow

L. E. Addison

Tech. Information

Tech. Pubs.

United Nuclear, Inc.

C. D. Corbit

F. E. Owen 